\title{
Tatar Alimlerden Rizaeddin B. Fahreddin (1859-1936) ve Hadisçiliği
}

BÜNYAMIN ERUL

Doç. Dr., ANKARA Ü. İÂHIYAT FAKÜLTESI

e-mail: berul65@hotmail.com

\begin{abstract}
Ridauddin b. Fahruddin (1859-1936): A Tatar Scholar of The Hadith. Ridauddin b. Fahruddin, a famous Islamic Tatar scholar, was born in 1859 in Almad-Tataristan. After completing his education he used to work in different duties like al-imam and al-mudarris (teacher) al-qadi and al-mufti in Orenburg and Ufa-Russia. He wrote more than 50 books and 410 articles and he left 40 volumes manuscripts. When he died in 12 April 1936 in Ufa, he had left a lot of valuable works. Furthermore he was the publisher of the journal of al-Shurah.

Because of his huge contribution to Islamic sciences two Ph.D. theses were prepared and published about him in Turkey; but none of them dealt with his contribution to The Hadith. He wrote on almost every aspect of Hadith. Because of this lack we wanted to make clear his views about The Sunna and The Hadith depending on his two important works on the hadith. One of this works is The Six Books and Their Authors (Kutub-i Sitte Ve Muellifleri), and the other is the Commentary of Jawamiu'l-Kalim (Cevâmiu'l-Kelim Serhi). We found out that his works also made important contributions to The Hadith and its history, although his works give us very important information on The Hadith and The Sunnah in Tataristan at his ages.
\end{abstract}

key words

Tatar, Ridauddin b. Fahruddin, Hadith, Commentary.

\section{Giriş}

İslam'ın Tataristan'a girişi, 2005 Ağustos'unda 1000. yılı kutlanan Kazan şehrinden daha eskidir. Tatarların İslamlaşma serüveni, İslam'ın bölgeye girişi, İslam'ın resmen kabul edilişi(922), Kazan Hanlığı'nın Yıkılışı (1552), II. Yekaterina döneminden Sovyet İhtilaline kadarki dönem (1762-1917), Sovyet İhtilalinden SSCB'nin dağılmasına kadarki dönem (1917-1988), SSCB'nin dağılmasından günümüze kadarki dönem şeklinde birkaç dönemde incelenebilir. ${ }^{1}$

1 Bu konuda geniş bilgi için bkz: İbrahim Maraș, Türk Dünyasında Dini Yenileșme, İstanbul, 2002, s. 17-18; Rızaeddin b. Fahreddin, Altın Ordu ve Kazan Hanları, notlandırarak çeviren: İlyas 
II. Yekaterina'nın 22 Eylül 1788 tarihindeki fermanıyla Ufa'da Orenburg Muhammedi Ruhani İdaresi adıyla bir müftülük kurulmuştur. Gerek hükümetin yumuşama politikaları, gerekse ekonomik gelişmeler, ilmi gelişmeyi de beraberinde getirmiş, böylece Tatarlar bazı büyük şehirlerde cami ve medreseler açabilmişler, kendi dini teşkilatları bünyesinde imam, molla ve muallimler yetiştirebilmişler, bu da bölgede dini ve ilmi faaliyetlerin yeniden başlamasını sağlamışır. XVIII. asrın sonlarından XIX. asrın ortalarına kadar İdil-Ural bölgesinden Türkistan'a giden ticaret kervanları birçok öğrenciyi de beraberinde taşımışırı. Buhara ve Semerkand medreselerinde okuyan bu öğrenciler İdil boylarında yeni medreselerin açılmasına öncülük etmişlerdir.

1885'den sonra usul-i cedid okullarının açılmasıyla bölgede, seviyeli bir ilim ortamı oluşmuştur. Ceditçiler ile Kadimciler (yenilikçilerle gelenekçiler) arasında yapılan tartışmalar, birçok konuda eserin yazılmasına, on kadar ilmi derginin çıkmasına vesile olmuştur. ${ }^{2}$

Bu makalede, kadim İslam merkezlerinden biri olduğu gibi, XIX ve XX. yüzyıllarda önemli bir ilim merkezi de olan Tataristan'daki hadis mirasının en önemli simalarından olan Rızaeddin b. Fahreddin'in hadisçiliği ele alınacaktır. Zira, onun hadis ilmine dair yaptı̆̆ tespitler ve ortaya koyduğu telifler, bölgede hadise verilen ehemmiyeti yansıtmaktadır. Onun hayatı ve eserleri hakkında Türkiye'de iki doktora tezi hazırlanmış ${ }^{3}$, birçok dilde ve ülkede pek çok değerli çalışmalar yapılmış ise de ${ }^{4}$, bildiğimiz kadarıyla hadis ile ilgisi ve hadisçiliği üzerine müstakil bir çalışma yapılmamıştır. İşte bu çalışmamızda, oldukça velut bir ilim adamı olan Rızaeddin b. Fahreddin'in bu sahadaki teliflerinden hareketle hadis ilmine hizmeti incelenecektir.

\section{Tataristan'a Hadis Illminin Girişi}

İslam'ı Tataristan havalisine taşıyan öncülerin, hadis alanında az ya da çok ilmi bir birikimi beraberlerinde taşıdıklarında şüphe yoktur. Mesela Altın

Kamalov, Kaknüs Yayınları, İstanbul, 2003, (Kitap müellifin Şura Dergisi'ndeki makalelerinden oluşmaktadır.); Mehmet Saray, "Altın Orda Hanlığı", DİA, II, 538-540; İsmail Türkoğlu, "Kazan", DİA, XXV, 134-136; Türkoğlu İsmail, "Kazan Hanlığı", DİA, XXV, 136-138.

2 Bkz: İbrahim Maraş, a.g.e, s. 18-23. XX. Yüzyılbaşı Tatar matbuatı hakkında yapılan bir çalışma, o dönem Tataristan'ında 312 gazete ve 89 derginin basıldığını ortaya koymaktadır ki bunlardan 47 gazete ile 29 dergi Kazan'da basılmış olup önemli bir kısmı dini ve ilmi içeriklidir. Bkz: XX. Yüzyıl Başı Tatar Vakitli Matbuatı, P. P. Gaynanov, P. F. Merdanov, F. H. Şekurov, Kazan, 2000.

3 Bunlardan ilki, İsmail Türkoğlu, Rusya Türkleri Arasındaki Yenileşme Hareketinin Öncülerinden Rızaeddin Fahreddin, İstanbul, 2000, ikincisi ise Ömer Hakan Özalp'in, Rızaeddin Bin Fahreddin, Kazan'la İstanbul Arasında Bir Alim, İstanbul, 2001 adlı eserdir.

4 Tataristan Milli Kütüphanesi tarafından yayınlanan Rızaeddin Fahreddin adlı bir kitap (Kazan, 2003), onun hakkında farklı dillerde yapılmış 588 çalışmayı zikretmektedir. 
Orda alimi Mahmud Bulgari'nin (1358) "Nehcu'l-ferâdis"5 adlı eserinde birçok hadisler kullandığı, 1552 yılında ise hadislerin derlendiği bir "Hadisler Ciyıntı̆̆ı" oluşturulduğu bilinmektedir. ${ }^{6}$

Tatarların ilim serüvenleri hakkında detaylı bilgi veren Rızaeddin b. Fahreddin, Rusya Müslümanları arasında Hadis ilminin tarihini dört devirde ele almaktadır:

"Bizim kendi memleketimizde atalarımız olan Bulgar Türkleri zamanında Tatarların (Mogollar) yönetimi altındayken Hadis ilminin yaygın olduğunu bilmiyorum. Bu mübarek ilmin mertebesi ve ona olan hürmet son zamanlarda anlaşıldı. Nitekim bu husus, Orenburg'da bulunan 1840 yılından itibaren tertip edilegelen bir defterde mevcut kısa bilgilerden, imamlık, müezzinlik ve müderrislik için imtahana giren kimselerin biyografileri, hocaları ve hadis konusunda neler okuduklarına dair sorulan sorulara verdikleri cevaplardan da anlaşılmaktadır. Buna göre daha sonra meşhur imam ve müderrisler arasına girecek olan bu talebelerden kimi "Hadis ilminden $A y$ nu'l-illim okuduk", bazıları "Tarîkatu Muhammediyye okuduk" diye yazmaktadırlar. Daha sonraları ise bazıları Hadis dersinde "Mişkâtu'l-Mesâbîh" okuduk demektedirler. Mişkât'ı okutan müderrislerin de bu eseri Hadis ilminin kaidelerine uygun biçimde okuttuklarını zannetmem. Sanırım onlar "Mirkat" şerhini esas alıp onu terceme etmektedirler.

Öteden beri bizim alimlerimiz arasında Hadis ilmini kendi usulü ve kaideleri ile bilen alimler Kursâvî, Ali Tüntârî ve Mercânî'dirler. Alimcân Bârûdî ve arkadaşlarından bazı zatlar ile, Hicaz'da bu ilimden istifade edip gelen 3-4 akranımızın bu doğrultuda inşaallah bizim kadirli seleflerimizin hayırlı halefleri olurlar diye ümit etmekteyim."”

Tatar alimler arasında Hadis İlminde en fazla müktesebatı olan merhum Rızaedin b. Fahreddin "Kutub-i Sitte ve Müellifleri" adlı değerli eserinde de

5 Eser, Tataristan Kitap Neşriyatı tarafından Kazan, 2002'de Kril harfleriyle Tatar dilinde neşredilmiştir.

6 Bkz: www.aliakis.org. Kazan Devlet Üniversitesi Lobaçevski Kütüphanesi kataloğunda Arapça 2329 numarada kayıtlı çok eski bir "Hadisler Cryıntı̆̆ı" bulunmaktadır. Talik bir hat ile yazılan ve başı-sonu eksik olan 4 varaklık bu risalenin ismi de yazarı da bilinmemektedir. İnceleme imkanı bulduğumuz bu elyazması risalede, ilk sayfada surelerin faziletine dair bazı hadisler, "Hadisler Hakkında Gelen Rivayetler" başlığı altında 40 Hadis ezberleme, Hadis nakletme, Hadisleri Kur'an'la test etme, işittiği herşeyi nakletmeme ile ilgili hadisler, "Fetva ve Nasihat Hakkında Gelen Rivayetler", "İlim ve Öğrenme Hakkında Gelen Rivayetler", "Alimler Hakkında Gelen Rivayetler" ve "Cahilliğin Yerilmesi Hakkında Gelen Rivayetler” şeklinde kırmızı mürekkeple yazılmış başlıklar altında muhtelif hadisler bulunmaktadır.

7 Rizaeddın b. Fahreddin, Cevamiu'l-kelim Şerhi, Kazan, 1996, s. 187. 
"Hadis İlmi ve Rusya İslamları" başlı̆̆ı altında önemli bilgiler vermektedir. O, Hadis İlminin Rusya'daki tarihini dört dönem halinde ele almaktadır:

“1. Devir: Hayret Devri: Kazan'ın Rusya hakimiyeti altına girdiği tarihten başlar. Bu devirde müslümanlar özgür değillerdi, İslam da resmi din olarak kabul edilmiyordu. Ayrıca Volga ile Ural arasında, Ak İdil ile Çulman boylarında Başkırd kavgaları devam edip duruyordu. Bu sebepten müslümanlar, ümitsizlik ve şaşkınlık içine düşmüş, ilim ve marifet yolunda bir adım olsun yürüme imkanı olmamıştır.

2. Devir: Dağistan Devri: Hissiz ve hareketsiz durmaktan bir netice çıkmayacağını anlayan Müslümanlar, akıllarını başlarına devşirip, binbir meşakketle de olsa Dağistan taraflarına bazı talebeleri tahsile göndermişlerdir. Bu talebeler orada ya kendilerinin açtıkları mekteplerde, ya da evlerinde çocukları okutmaya başlamışlardı. Bu devirde, Arapça Sarf ve Nahiv ile Fıkıh ilimleri revaçta olmuştur. Dağistan'da okuyan talebelerin hatları güzel olduğu için memleketimizdeki yazma eserler bunlar ve talebeleri tarafından yazılmıştır. Onların okudukları ilimler faydalı olmuş, halkın ahlak ve adetlerine de güzel tesir etmiştir. Bu devirde her ne kadar Kur'an ve Hadis ilimleri okutulmamış ise de, halk arasında güzel ahlak, İslam kardeşliği, edep ve insaf yaygın hale geldiği için bu devre "Altın Devri" denilse yeridir.

3. Devir: Skolastik Devir: Başkırt kavgalarının sona erip Orenburg şehrinin kurulduğu tarihten H. XIV. Asrın başına kadar olan zamandan ibarettir. Sahra halkları Rusya'ya bağlılıklarını kabul ettikten sonra Türkistan ile Rusya arasında ticaret yolları açılınca, ticaret kervanlarıyla birlikte Rusya müslümanları Buhara taraflarına tahsil amacıyla gidip gelmeye başlamışlardır. İşbu vakitlerde Rusya Devleti de İslam dinini resmi olarak tasdik ettiğinden, Buhara'dan gelen büyük alimler buralarda medreseler açmışlar ve serbest bir şekilde talebe okutmuşlardır. Ancak, Buhara'daki dersler, Esâlîbi Yunan, kitap dibaceleri, şerh ve haşiyelerin bahis ve munazaraları olduğundan, bunları rehber edinmiş olan bizdeki medreselerde de Kur'an ve Hadis ilimleri ile ciddi surette iştiğal edilmemişti. Gerçi Kursâvî, Şeyh Ali Tüntârî ve Mercânî gibi büyük zatlar bazı hadis kitaplarından okutmuşlarsa da, bu dersler başkaları nezdinde itibarsız kalacağı korkusuyla talebeler skolastik dönemin mevcut derslerinden başkasına rağbet etmedikleri için pek önemli sayılmazlar.

4. Devir: İntibah (Uyanış) Devri: H. XIV. Asıın başlarından itibaren başlar. Frenk alimlerinin İslam'a yönelik taarruzlarına karşı cevap vermek şöyle dursun, meseleyi açıkça anlamaktan dahi aciz olduklarını anlayan skolastik alimler, hatalarını anladılar ve gerçek ilim yoluna girmeleri gerektiğini itiraf ettiler. Onlara cevap vermezden evvel, hakiki İslam'ı öğrenmeleri 
gerektiğini gördüler. İşte bundan sonra Kur'an ve hadis ilimlerini tahsil için yol açıldı. "Tavuk pazarında deve satılmaz" denildiği gibi, bu ilimlerin tahsil edileceği yerler de Buhara değil, belki Hicaz ve Mısır idi. Bazı talebeler buralara giderek yeni ilim ve maarif tahsil ettikten sonra, memlekete döndüklerinde umumi bir uyanışa sebep olmuşlardır. Böylece skolastik ilimlerin yerini, şeriatın esası olan Sünnet ilimleri almıştır. Bundan anlaşılmaktadır ki memleketimizde Hadis ilminin yaygınlaşması "bugünki" denilecek kadar yeni bir şeydir. Hadis ilmini usul ve kaidelerine göre tahsil etmek yaklaşı olarak H. XIV. Asrın başlarından itibaren başlamıştır. Kitap, Sünnet, Siret ve Sahabe Biyografileri konularında gençler, memleketimizdeki yaşlı alimlere göre daha iyidirler. Bunlar arasında sadece (Buhârînin) Sahih'i değil, Kutub-i Sitte'nin tamamını mütalaa etmiş gençler vardır. Bizim bildiğimize göre, memleketimizde ciddi surette hadis ilmine hizmet edeceklerin başında Alimcân Bârûdî Hazretleri olsa gerek. Bu zat, Kutub-i Sitte'nin imamı olan "el-Câmiu's-Sahîh" kitabını ders programına koyup, bizzat kendisi onu muntazam şekilde okutmuş, hatta birkaç defa onu hatmetmiş ve güzel talebeler yetiştirmiştir. Medine'de Hadis-i Şerif müderrislerinden olan Seyyid Muhammed Ali ez-Zâhir el-Medenî el-Vitrî H. 1314 tarihinde memleketimize geldiğinde onun ders halkalarına pekçok talebe, muallim, imamlar ve müderrisler iştirak etmiş, ondan Hadis dinleyerek bu ilmin lezzetini almışlardır. Şimdi bu günümüzde dini medreselerimizin ekserinde Kur'an-1 Şerif ve Hadis ilimleri umumi diyecek bir surette ders olarak okutulmaktadır."

\section{HAYATI VE HADISÇILIĞi}

\section{A. Rızaeddin b. Fahreddin'in Hayatı}

"İdil-Ural Müslümanlarının uyanış devrindeki en büyük alimlerinden; bölgenin milli tarihinde ve matbuatın gelişmesinde çok büyük emeği olan, sayısız eseri ve büyük hizmetleri ile Rusya Müslümanları üzerinde derin izler bırakan, İslam'a karşı devlet eliyle savaş açıldığı 1923-1936 yılları arasındaki müftülüğünde Rusya Müslümanlarını birleştiren, Osmanlı modernleşmesinin fikrî ve siyasî yönelişlerini yakından takip eden, doğrudan ve dolaylı yollarla son dönem Osmanlı aydınlarını etkileyen alim, tarihçi, gazeteci, kadı" olan Rızaeddin b. Fahreddin, Tatar ziyalıları (aydınları) içerisinde birçok branş ile ilgilenmiş, çok yönlü ve üretken ilmi bir şahsiyettir.

8 Rizaeddin b. Fahreddin, Kutub-i Sitte ve Müellifleri, Orenburg, 1910, s. 50-54. (Özetle).

9 Özalp, a.g.e, s. 5. 
Tataristan'ın Elmed şehrine $12 \mathrm{~km}$. mesafedeki Kiçüçat Köyü'nde doğdu. Tahsilini Bügülme’ye bağlı Şilçeli Köyü'nde yaptı. 1889'da İlbek Köyü’nde imamlık ve müderrislik yaptı. 1891'de Orenburg müftülüğüne kadı seçildi, aynı yıl ahundluk (üst düzey alim) rütbesini aldı ve Ufa'ya taşındı. 1906 Mayıs'ında kadılıktan istifa ederek Şura Dergisi'ni çıkartmaya başlad1, birçok dergi ve gazetelerde yazılar yayınladı, 1897'den itibaren muhtelif eserler neşretti. 1918'de tekrar kadılığa, 1922'de ise Müftülük makamına seçildi. 7 Haziran 1926'da Mekke Kongresi'ne katıldı ve orada ikinci vekil olarak görev yaptı. Ömrü boyunca elliden fazla telif eser bastırd1, birçok makale yayımladı. Büyük boy ve herbiri 600 varaklık 40 ciltten oluşan -bir kısmı telif, bir kısmı istinsah olan- yazma eserleri ise Rusya İlimler Akademisi Ufa İlim Merkezi İlmi Arşivi'nde saklanmaktadır. ${ }^{10}$

Rızaeddin b. Fahreddin, büyük maddi sıkıntılar içerisinde geçirdiği müftülük yıllarının ardından, 12 Nisan 1936'da, geride ölmez bir isim bırakarak bu dünyadan ayrıldı. ${ }^{11}$

"Medresenin verdiği derslerden ziyade, kendi kendisini yetiştirerek Arapça, Farsça ve Rusça öğrendi. Çağın fikir akımlarını, medeni milletlerin hayat görüşlerini inceleyip, ilimdeki gelişmelerle İstanbul, Kahire ve Beyrut gibi merkezlerin matbuatını -kitap, süreli yayın- yakından takip etti. Bir ara Rusya'da bulunan Cemaleddin Efgânînnin sohbet ve ilim meclisinde bulunduğu gibi, dönemin yerli-yabancı pek çok ilim ve fikir adamı ile -bir şekilde bağlantı kurarak- görüş alışverişinde bulundu.

Sovyet hükümetinin dine karşı açtığı yoğun-sert propoganda ve savaşa rağmen, Rusya'daki müslümanların çoğunu, başında bulunduğu Ufa Diniye Nezareti etrafında birleştirdi. Onbinlerce mescidin kapatılıp ekmek deposuna veya dinsizler kulübüne dönüştürüldüğü bir zamanda, bölgesinde pekçok mescidin açık kalmasını; mescidlerde dînî dersler verilmesini; imam ve müezzin çocuklarının fen okullarına alınmasını; imamlardan alınan aşııı vergilerin kaldırılmasını; tüm Rusya, özellikle de bölge müslümanlarının tarihleri için paha biçilmez bir hazine olan Diniye Nezareti Arşivi'nin korunmasını ve müftülükçe İslam Mecellesi adlı bir mecmua çıkarılmasını sağladı." ${ }^{12}$

Rizaeddin b. Fahreddin'in yaptığı bu hizmetlerin asıl önemi, bütün bunları Rusya'daki açlık ve kıtlık gibi musibetlerin yanısıra, bilhassa Bolşeviklerin özelde ilim adamlarına, genel olarak da bütün müslümanlara her türlü

10 Hayatı ve eserleri hakkında bkz: Rızaetdin Fahretdin, Terceme-i Halim, Ruhiyat Neşriyat, Kazan, 1999; İbrahim Maraş, a.g.e., s. 89-91.

11 Özalp, a.g.e, s. 7.

12 Özalp, a.g.e, s. 5-7. 
baskı ve şiddeti reva gördüğü ve sırf bu zulümlerden dolayı birçok ilim adamının çareyi bölgeyi terketmekte bulduğu kelimenin tam anlamıla "zor zamanda" başarabilmiş olmasıdır. Tabiri caiz ise o, her türlü riski göze alarak, binbir türlü meşakkate katlanarak bölge müslümanlarına manevi öncülük görevine soyunmuş, o sıkıntılı şartlarda dahi, kaledeki son murabit olarak ilimle, kalemle cihad etmiş, belki de öyle bir ortamda yapılabileceklerin çok fazlasını gerçekleştirebilmiştir.

Elbette bunları yaparken zaman zaman hayli sıkıntılar yaşamıştır. Mesela 1920'de Ufa'da tutuklanıp hapse atılmış, kendisi içerdeyken evi basılarak bütün evrakları alınmıştır. 1931'de Moskova'ya çağırılmış ve "Rusya'da dine ve hürriyetlere karşı bir baskı ve zulüm yok!" mahiyetindeki bir beyanname imzalaması teklif edildiğinde o "Beni mazur görünüz. Buna imza atamayacağım. Bunlar hilaf-i hakikattir. Dinimizde (ise) yalan söylemek yasaktır. İslam ülkelerini böyle bir yalanla aldatamam!" diyerek reddetmiştir. Ölüm ve işkence tehditlerine de aldırmayan Rıza Fahreddin "O halde buyurun öldürün! İstediğinizi yapabilirsiniz, böyle bir yalana asla imza atmayacağım. Sizden müslümanlara yaptığınız baskı ve zulümleri terkedip; din adamlarını kitleler halinde sürgün ve hapsetmeyi, cami ve medreseleri kapatmayı durdurmanızı istiyorum!" karşılığını vermekten çekinmemiştir. ${ }^{13}$

Rıza Fahreddin, tarih, felsefe, pedagoji, edebiyat, dil bilimi, sanat, coğrafya, arkeoloji, arkeografya, şecere/soybilim, epitafiye (mezar kitabesi bilimi), tıp, nümizmatik (para bilimi), hukuk, astronomi, halk ağzı, din tarihi ve daha başka ilimler ile pek derinden ilgilenmiş ve bunlar konusunda çok sayıda kıymetli makale ve eser yazmıştır. Kendisi, Tatar medeniyeti, ictimâî ve fikrî tarihinde edebiyat ve medeniyet tarihi ile felsefe, tarih, dünyevî ve fennî bilimleri ve marifeti halk arasında yayan bir alim olarak bilinmekte olup, asrın cemiyet hayatında hüküm süren kötülüklerden kurtulmanın tek yolunun ilim ve marifet (kültür/bilgi, öğrenme) olduğunu söylemiştir. ${ }^{14}$

Diniyye Nezareti'nde bulunan her alana ait binlerce el yazmas1, ve İslam aleminde o yıllarda basılan farklı mezhep ve meşrebe ait birçok kaynağ kullanmanın avantajı ile çok yönlü bir alim olan Rızaeddin Fahreddin'in ilmi kişiliğini, mezhep ve meselelere yaklaşımda hoşgörülü oluşunu, mutaassıp olmayışını onun şu ifadeleri net bir şekilde ortaya koymaktadır:

"Biz, tabiatımızda ve ahlakımızda bulunan şevk sebebiyle hayatımızda pekçok terceme-i hâl, tabakât, tarih ve menakıb kitapları mütalaa ettik; 
sadece İslam alimlerinin değil, yabancı milletlerin meşhur adamlarından birçoklarının terceme-i hallerine -icmalen de olsa- âşinalık peyda ettik; birbirine muhalif meslekler ve ateş ile su gibi birbirine zıt fikirler ile karşılaşmış bulunduğumuzdan gönlümüze bir genişlik; herşey hakkında soğukkanlılık, hiçbir söz karşısında şaşırmamak, kızmamak, hayrete kapılmamak, hayran olmamak tabiatı hasıl oldu. Bunu Allah'ın bir feyzi saydık da, itikad ve mesleklerin hata-sevablarını ölçmek için doğru bir mizan edindik ve bundan faydalanma yolunu tuttuk" demektedir. ${ }^{15}$

\section{B. Rızaeddin b. Fahreddin'in Hadis Ile Ilgili Eserleri:}

Rızaeddin b. Fahreddin, çok üretken bir ilim adamıdır. Medreseler için hazırladığı ders kitaplarından, halkı bilinçlendirmeye yönelik hikaye ve romanlara kadar, farklı branşlarda irili-ufaklı birçok eser yazmıştır. Bu eserlerden bir kısmı, halen elyazması halinde basılmayı beklemektedir. Tarih, edebiyat, eğitim, ahlak, seyahatname, sosyoloji, biyografi, İslami ilimler vb. muhtelif alanlarda 14'ü elyazma, 50'si matbu, 12 tanesi de başka kitaplar içerisinde veya sonradan basılan olmak üzere toplam 76 eser telif ettiği; Şûra, İslam Mecellesi, Asrî Müslümanlık vb. dergilerde toplam 410 yazı/ makale yayınladığı tespit edilmiştir. ${ }^{16}$

Rızaeddin b. Fahreddin'in hadis ile ilgili eserleri ise şunlardır:

1. Muhammed Aleyhisselam, Orenburg-1908, $64 \mathrm{~s}$.

Şura Dergisi tarafından “Dîn-i mübîn-i İslam'ın zuhurundan, Rasûl-i Ekrem Efendimiz Hazretleri'nin neseb-i şeriflerinden, vefat ettiği güne kadar olan büyük hâdise ve maceralardan bahsettiği ve en muteber asıllardan alınarak tertip edildiği cihetle mektep talebeleri için faydalı olduğu bildirilen ve kapağında "Fahr-i kâinat efendimiz Rasûl-i Ekrem (s.a.v) Hazretleri'nin mübarek şeceresi, nesil ve nesebleri ile bazı ahvalinin yazıldığı bir risale" şeklinde takdim edilen eser Orenburg Vakit Matbbası'nın açılışı için yadigâr olarak kaleme alınmış olup 1909'da aynı matbaanın ilk kitabı olarak basılmiştır.

Medhal, (Hz. Peygamber'in) doğumu, yetişmesi, risaleti, hicret, Medine ve meşhur hâdiseler, vefatı, ahlak ve sireti, çocukları, torunları, zevcat-1 tahiratı, amcaları, halaları ve halifeler bölümlerinden oluşan eserin sonunda isimler indeksi bulunmaktadır. ${ }^{17}$

15 Özalp, a.g.e, s. 109. (Mercânî, Kazan, 1915, s. 415'ten naklen.)

16 Ozalp, a.g.e, s. 123-267.

17 Özalp, a.g.e, s. 172-173. 
2. Illm-i Hadis'den Kutub-i Sitte Ve Müellifleri, Orenburg-1910, Vakit Matb. $135 \mathrm{~s}$.

Buhârî, Muslim, Ebû Dâvud, Tirmizî, Nesâî ve İbn Mâce'nin kitapları ile birlikte İmam Mâlik'in el-Muvatta adlı değerli eserini de inceleyen müellif, kitabın kapağında bu eserini, "Hadis ve Sünnet alimleri nezdinde maruf olan Kutub-i Sitte ve şerhleri, müelliflerinin terceme-i halleri ve Hadis ilmi hakkında gerekli bazı faideleri müştemil bir risaledir" şeklinde takdim etmektedir.

"Hediyyem" başlığı altında Orenburg'daki Hüseyniye Medresesi'ndeki İdadiye talebelerine Hadis ilminden ders okuttuğu vakit, bu ilme dair bazı bilgileri bir araya getirerek bir risale tertip etmeye söz vermiş olan müellif, adı geçen medreseden ayrıldıktan sonra, -o zamanki talebeleri mezun olsalar da- verdiği sözü yerine getirmek maksadıyla "Kutub-i Sitte Müellifleri" adıyla bu risaleyi yazdığını ve o talebelerine hediyye ettiğini belirtmektedir. ${ }^{18}$

3. Cevâmiu'I-Kelim, Kazan-1911, s. 32.

"Rüşdiye Mekteplerindeki çocuklar için hem ahlakı hem de Arapçayı geliştirmeleri için bir kitap yokluğundan şikayet edenlere Suyûtî̀nin el-Câmiu's-sağîr adlı eserinden hadisler seçmiştir. Sonra Mevzûât kitaplarında uydurma oldukları belirtilen rivayetleri düşürerek seçkinin yarıdan fazlasını çıkartmıştır. Kalan hadislerden çoğunu Kutub-i Sitte'de de bulmuştur. Birkaç adet şüpheli hadis kaldı ise de o haliyle Kazan-1326'da basılmıştır. Sansür tarafından hadisler bozulduğu için üç-dört defa dizilip-yazılmıştır." ${ }^{19}$

Alfabetik olarak tertip edilen risalede, harekeli ve rakamlı olmak üzere toplam 317 hadis bulunmaktadır. Müellif, talebeler için ahlaka dair Arapça fasih ve zevkli risalelerin bulunmadığını, bunun üzerine "Her ne kadar bu hususta yeterli birikimimiz yok ise de" diyerek bu risaleyi kaleme aldığını, el-Câmiu's-sağîr kitabından zamanının el verdiği ölçüde sosyal ve milli hayatı dikkate alarak uygun gördüğü hadisleri seçerek bu risaleyi tertip ettiğini belirtmektedir. Ona en layık isim olarak da "Cevâmiul-kelim" adını verdiğini, lafız ve harekelerin tesbitinde Kâmus ve Tâcu'l-arûs kitaplarına müracaat ettiğini söylemektedir.

Azîzîi ${ }^{20}$ ve Hanefî (?) tarafından zayıf olduğuna işaret edilen hadisleri nakletmediğini belirten müellif, risalenin tertibinin tamamlanmasından son-

18 Rizaeddin b. Fahreddin, Kutub-i Sitte ve Müellifleri, s. 3.

19 A.g.e, s. 113.

20 Adı, Ali b. Ahmed el-Bûlâkî olup, es-Sirâcu'l-munîr adlı şerhin sahibidir. Bkz: Mücteba Uğur, "el-Câmi's-sağîr" Di், VII. 114. 
ra muhaddis Muhammed b. Derviş el-Hût adlı alimin "Esna'l-metâlib" adlı kitabını gördügüüü, hadisleri onunla karşılaştırdı̆̆ını ve bazı hadisler hakkında eleştiriler bulunduğunu anladığını hatırlatmaktadır. Ancak adı geçen alimin bu hadislere zayıf derken bunu kat'i surette de iddia etmediğini, sadece bazı muhaddislerin söylediklerini beyan ettiğini hatırlatır. Dolayısıyla bu hadisleri kitapta öylece bıraktığını, hata ettiyse Allah'dan af buyurmasını istemekte ve bu konuda niyetinin salih olduğu imasıla "İnnema'l-A'mâlu bi'n-Niyyât=Ameller niyetlere göredir"'21 hadisi ile son vermektedir.

Risalenin sonunda Suyûtî ve mezkur eserinden söz etmiştir. (s. 31-2)

4. Cevâmiu'l-kelim şerhi, Orenburg-1916, 525 s. (Kazan-1996 ofset)

5. El-Belâğu'l-mübîn ve şerhi, (1918-1924): Bu iki değerli şerhi ve şerhçiliği hakkında makalenin sonunda genişçe bilgi verilecektir.

\section{Rızaeddin b. Fahreddin'in Hadis IImi Hakkında Tespitleri}

Kutub-i Sitte ve Müellifleri adlı eserine "Medhal" başlığı altında yaptığı girişte, kitabın içeriğinin anlaşılabilmesi için, umumi surette de olsa Hadis ilmi hakkında bazı bilgilerin verilmesinin lüzumuna işaret eder. Dolayısıyla bu kısımda Rızaedin b. Fahreddin'in Hadis İlmine dair görüşleri, ağırlıklı olarak bu kıymetli eserine dayanılarak verilecektir.

\section{Hadis ve Sünnetin Önemi}

Rızaeddin b. Fahreddin'e göre "Hadis, din emirlerine müteallik olarak Fahr-i kainat Efendimiz Muhammed (s) Hazretleri'nden sadır olan kaviller, fiil ve takrirlerden ibaret olur. Sünnet de işte budur." Müellifin burada Hadis'i tarif ederken, "din emirlerine müteallik olarak" kaydını getirmesi kadar, orada düştüğü dipnotta da bazı alimlerin Hadis'i, sadece kavle tahsis ettiklerini, Sünnet'in ise, bid'atın karşıtı, ashabın ameli ve farz ile vacibe mukabil anlamlara da geldiğini de hatırlatması önem arzetmektedir. ${ }^{22}$

Kur'an'dan sonra şeriatın ikinci aslının sünnet olduğunu, hadislerin belli bir kavme mahsus olmayıp, herkes, her yer ve zaman için hüccet olduğunu, onlarla amel etmekten menetmeye kimsenin hakkı olmadığını belirtir. Bu hususta ne kadar büyük ve şöhretli zatlar olsalar da, neticede ümmetten biri olan kimselerin sözleri ölçü alınmaz. Öyle olsaydı, hadis ve sünnet ile iştiğal edileceğine onların sözleri yazılırdı. Bundan dolayıdır ki, elinde Muvatta', Sahîh-i Buhârî ve Sahîh-i Muslim ya da başka bir Sünen kitabı bulunan

21 Buhari, Bed'u'l-Vahy 1, I. 2.

22 Kutub-i Sitte ve Müellifleri, s. 6'daki 2. ve 3. dipnotlar. 
kimse, bu kitaplardaki hadislerle amel edebilir. Hatta bu kitaplardan ders yapacaklar da işbu niyetle ders yapmalıdır. Zira ilimden maksad, ameldir. Kur'an ve hadislerle amel etmek için müctehit olmak şart değildir, belki Arapçayı, nasih-mensuhu bilmek kafidir. Amel etmek için ne kadar hadis varsa herbirini ihata edip bitirmek lazım değildir.

Ruzaeddin b. Fahreddin'e göre İslam dininde birinci derecede itimat edilecek delil Kur'an, sonra ümmet tarafından ittifak ile kabul edilmiş 'amelî sünnet', ondan sonra da rivayet veya delaletinde ihtilaf edilmiş 'kavlî sünnet"tir.

\section{Hadislerin Değeri}

Mütevatir haberin "Aklen biraraya gelmeleri mümkün olmayan muhtelif birçok kimseler tarafından rivayet edildiğini" söyleyen müellif, dipnotta da "Mütevatir haber rivayetlerinde adalet şart değildir" açıklamasına yer verir.

Meşhur haber ve haber-i vahid ile amel edildiği halde, delillerinin kat'î olması şart koşulan itikadî konular onlarla sabit olmaz.

Rasul-i Ekrem'den doğrudan doğruya işiten kimselere göre hadislerin herbiri mütevatir hükmünde olup, ilm-i yakin ifade eder. Bu sebeptendir ki, bütün müslümanların Ashab asrında ittifak hasıl olan amellerle, aynı şekilde amel etmeleri lazım gelir. Farz namazların vakitleri, rekatları ve zekat mikdarları buna dair misallerdir. ${ }^{23}$

Mütevatir olmayan bir hadisin sahih olduğunda muhaddisler tarafından bir tartışma olmasa dahi, buna bakıp da 'Bu hadis kesin olarak Rasulullah'dan sadır olmuştur' diye hükmetmek mümkün olmaz. Zira, sahabe de dahil, peygamberlerden başka kimse masum olmadığından, yanılmaları, unutmaları veya bir hadis yerine ikincisini nakletmeleri ya da mana ile rivayet etmeleri caizdir. Bu nedenledir ki, mütevatirden başka hadisler ile yakîn (kesin bilgi) hasıl olmaz. Yakîn hasıl olmamış hadislerle de tabii ki, itikada dair bilgiler sabit olmaz. Bazı akide kitaplarında, kıyamet alametleri hakkında sadır olan hadislere binaen, Deccal'ın çıkması, Mehdî ve Hz. İsa'nın inmesi gibi birçok şeyler zikredilmiş ise de, büyük bir ihtimalle bunlar, kitaplarını yalnız kat'î surette sabit olan itikadlara hasretmemişler, belki yanısıra zannî olanları da almışlardır. Pekçoklarının, fürûdan olan 'imamet' bahislerini akaid kitaplarına almaları bizim zannımızı teyid etse gerektir. ${ }^{24}$

Hadis rivayet etmek için, elde muttasıl bir sened olması da şart değildir. Nüshasının doğruluğunda şüphe olmamak şartı ile Kutub-i Sitte veya ma-

23 A.g.e, s. 7, 9.

24 Kutub-i Sitte ve Müellifleri, s. 26-27. 
ruf müsnedlerde olan hadisleri nakletmek -muttasıl bir senedi olsun veya olmasın- doğrudur. Muttasıl senedler tahsil etmek, yalnız teberrük kabilinden bir şeydir. Kutub-i Sitte'de olan hadislerden -muhaddisler tarafından istisna edilmiş beş on adedden başkaları- 'sahih' görülmekte ve sahih hadislerden Buhârî ile Muslim'in ittifak ettiklerine 'müttefakun aleyh' denilmektedir. 'Müttefakun aleyh' tabir edilen hadisler hakkında muttasıl ve merfu' olmak şartı ile İbn Salah: “Ümmet, Buhârî ve Muslim'in ittifakla naklettikleri hadislerin sihhatinde, onun hak ve doğru olduğunda ittifak etmiştir" demiştir. ${ }^{25}$ Fakat İbn Salah'ın bu iddiasına bazı zatlar, özellikle İbnu'l-Hümam ile Hanefilerin son alimleri razı olmamış ve şöyle demişlerdir: "Ümmetin bunların hadislerini ittifak ile kabul etmeleri, başkalarına göre senedleri itimadlı olduğu cihetindendir. İsnadı muhkem olan herbir haber-i vahid bu hükümde olup, ameli gerektirmektedir ve 'müttefakun aleyh' olan hadislerin ayrı bir imtiyazları yoktur". ${ }^{26}$

Rizaeddin Fahreddin'e göre "Rasulullah'ın her ameli (fiili) veya her sözü uyulması vacip olan 'din' değildir. Onun ibadet olarak yaptığı amelleri vardır; kendisine has veya tabii olan şeyleri vardır. O zamanın örfüne binaen söyledikleri sözleri vardır. Bir fiilin veya sözün 'din'(den) olması için, Hz. Peygamber tarafından 'din' adı ile ümmete tebliğ edilmesi şarttır.

Lügat açısından bid'atin, "misli/örneği geçmemiş yeni bir iş" manasına geldiğini ve dünyevî işlerde, âdetlerde bid'atin olmadığını belirten Rızaeddin Fahreddin, bid'atin şer'î manasını ise "Kitab ve sünnette bulunmayan, Rasulullah'ın sahabileri asrında amel edilmeyen bir itikad ve ameli, din adı ile ihdas etmek" diye tanımlamaktadır. ${ }^{27}$

\section{Gaybî Haberler}

Dünyevî ve Gaybî konular ile ilgili haberleri de ele alan Rızaeddin Fahreddin'e göre Peygamberler, Allah Teala hazretlerinden risaleti tebliğ etmek, ayrıca gaibden haber vermek hakkında gerek kasden, gerekse unutarak hataya düşmekten uzaktır. Fakat bunlardan başka, diğer insanlar gibi, yanılmaları ve hata etmeleri mümkündür. Zira risaleti tebliğ, ya da gaybdan haber verme dişındaki şeylerin risalet ile münasebeti olmadığından, onlarda olan kusurlar, risalete ait değildir. Bir peygamber için sanat ilminden ve yazı hünerinden habersiz olmak ayıp olmadığı gibi, tabii haller ve genel olarak dünyevi ilimler ile âşina olmamak da ayıp olmaz. Bununla

\footnotetext{
25 Ulumu'l-Hadis, s. 12.

26 Kutub-i Sitte ve Müellifleri, s. 31-32.

27 Bkz: İslam Mecellesi, S. 7-8, 1925, s. 257-260.
} 
birlikte, akılları kamil, anlayışları yüksek olduğundan tebliğden başka hususlardaki hataları da pek nadir olur. Burada Hz. Peygamber'in Medine'ye vardığında halkın hurma aşılamasına müdahelesi neticesinde mahsülün zayıf kalmasını örnek veren müellif, şu tespiti yapmaktadır: "Binaenaleyh, fen ve son tecrübelere aykırı surette dünyevi işlere dair hadisler olsa veya tıp kaidelerine aykırı surette bazı iddialar içeren eserler görülse, hadisleri asıl kabul edip de, tecrübe ile malum olan, fen ile ispatlanan şeyleri İslam dini ve Hadis adına inkar etmek caiz olmaz. Böyle bir tutum, İslam dininin esası olan birşeyi ilim ve hakikata zıt göstermek olacağından, gerçekte İslam dinine cinayet olur. Hadis ve Rasulullah hazretlerine hizmet bu değildir. Belki bu şey, din düşmanlarının ellerine eleştiri kozu vermekten başka birşey değildir.

Ameli hükümlerle ilgili hadislerin metinlerini, müctehidler teftiş ve tedkik etmiş, icabına göre onları kabul veya reddetmişlerdir. Onlar, kendi vazifeleri olmadığı için gaybî veya dünyevi işlerle ilgili hadisleri tedkike lüzum görmemişlerdir. Zira bu iş, müctehidlerin değil, gerektiğinde asrımızın ictimaî ve umranî alimlerine aid bir vazifedir. ${ }^{28}$

Rızaeddin Fahreddin, konu ile ilgili açıklamalarını şöyle sürdürmektedir:

"İtikad babında yakînî deliller lazım geldiğini, Buhârî ve Muslim hadislerinin de diğer sünen kitaplarından farkı olmadığını iddia eden Hanefi mezhebine tabi bazı alimlerin akaid hakkında tertip ettikleri eserlerde, Hz. İsa'nın ineceği, Ye'cuc ve Me'cuc'ün çıkacağı, güneşin batıdan doğacağı vb. başka haberleri almalarının sebebi bizlere malum değildir. Fırat Irmağı'ndan altın çıkacağı vb. pekçok Buhârî ve Muslim hadislerindeki haberleri de yazmadıklarının sebebi de malum değildir. Halbuki ya her birini yazmak, yahud hiçbirini yazmamak gerekirdi.

Maamafih, kıyamet alametleri hakkındaki hadisleri teftiş etmekte bu gün bir mecburiyet yok, ama gelecekte mecburiyet olmayacağından da emin değiliz. Akıllara hayranlık veren keşifler sayesinde yahut içtimai ve medeni inkilaplar sebebiyle bunlar hakkında çeşitli tetkiklerin yapılmasını gerektirecek güçler meydana çıkar.

"Mehdî" adı ile Müslümanlar arasında ortaya çıanları gören İbn Haldun, bu konudaki hadisleri teftiş etmeye mecbur kalmış, neticede hüccet sayılabilecek hadise rastlamadığını ilan etmiştir. Hz. İsa'nın ineceği ve Deccal'ın çıkaca $\breve{g} ı$ hakkında da bu şekilde bir mecburiyetin çıkmayacağını kimse iddia edemez. Hatta bugüne kadar gelip geçen alimler içinde, 'Deccal'nn çıkması, hurafelerin yaygınlaşmasına; Hz. İsa'nın inmesi ise, hakikatın zuhuruna bir işarettir' diyenlerin varlı̆̆ı malumdur.

28 Kutub-i Sitte ve Müellifleri, s. 32-35. 
"Güneşin battıktan sonra arşın altına varıp secde ettiğine dair" rivayet edilen hadisi hakikata hamledip susanlar, ya da Katade, Mukatil, Zeccac, Kelbî ve İbn Kuteybe gibi eski asırların faraziyeleri noktasından söz söyleyenlerin hey'et-i alem hususunda olan zanları fen ve ilmi cihetten gelişmiş asırlar ahalisi için hüccet değildir. Dünyevi işler hakkında Rasul-i Ekrem'in sözüne uyma vacip olmayınca, Kelbî ile Zeccac sözüne uyma ne gibi bir delil ile vacip olacaktır? Güneşin batarken hiçbir yere gitmediği, belli bir yerde durmadığı günümüzde ilmi ve hatta his ve gözlem açısından dahi ispat olunmaktadir.

Bunun içindir ki günümüzde hadis okutan zatların, mezkur hadisleri öğretirken, bugünki fen doğrultusunda, gözlemlere ters düşmeyecek şekilde anlam vermesi gereklidir. "Hiç bilenlerle bilmeyenler bir olur mu?"29

\section{Hadis Kritiği}

Hadis ravilerinde aranan akıl, adalet ve büluğ gibi şartların izafi olduğunu, bir muhaddis tarafından adil görülen bir ravinin, diğeri tarafından cerhedilebildiğini belirten müellif, birçok muhaddisçe 'sika, imam ve hafız'olarak görülen ve hadisleri Buhârî tarafından kabul edilen Ahmed b. Salih Ebû Cafer et-Taberî el-Mısrî hakkında İmam Nesâ̂înin 'ğayru sika velâ me'mûn' (sika olmadığı gibi, güvenilir de değil) demesini örnek olarak zikretmektedir. İşte hadislerin sahih olup olmadığına dair tartışmalar buradan çıkmaktadır. Bu nedenledir ki, 'Bu hadis, fülan muhaddise göre sahih, fülana göre sahih değil veya zayıftır' denilmesi gerekmektedir. ${ }^{30}$

Muhaddislerin hizmeti, isnadı teftiş etmektir. Bir hadisin senedi, onların kaidelerine uygun ise sahih, aksi takdirde değildir. Ancak görev burada bitmemektedir. Belki en büyük hizmet, 'metin' teftişinden ibarettir. Bu ise, mütehassıs alimlere mahsus bir vazifedir. Bazen, muhaddisler nazarında sahih olan hadisler, Kur'an'a muhalif olmak, akli delillere ters düşmek bahanesi ile mütehassıs alimler tarafından terk, yahut tevil edilmektedir. Mesela, Hz. Ömer ve oğlu Abdullah'ın rivayet ettikleri “Ölü, ailesinin ağlaması sebebiyle azab görür" hadisini Hz. Aişe'nin: "Size Kur'an yeter! 'Kimse, kimsenin günahını yüklenmez’ diye, Kur’an’a aykırılığını sebep göstererek reddettiği rivayet edilmiştir. ${ }^{31}$

H. I. asırda meşhur haberler, haber-i vahid derecesinde olduğundan, burada zikrettiğimiz ihtimallerden onlar da salim değildir. Zira hadislerde yalnız mana ile nakletmek caiz olduğundan, herkesin kendi anlayışına göre 
nakletmesi tabiidir. Binaenaleyh, onlar ile de yakîn ve kat'î hükümler sabit olmaz. "Meşhur haberleri reddetmek bid'attir" sözü, eğer muteber zatlardan sadır olmuşsa, şüphesiz bu söz, itikad ile ilgili konulara göre değil, belki amellerle ilgilidir.

Adalet ile ilgili ihtilaflar sebebiyledir ki, hadis imamları tenkid edilmiş hadis nakletme töhmetinden kurtulabilmiş değildir. En büyük ve muteber muhaddislerden olan Buhârî ve Muslim, Mürcie, Şia, Kaderî, Cehmî, İbadî vb. bid'at mezheplere mensup kişilerden hadis nakletmekle töhmet edilmişlerdir. ${ }^{32}$

Daha sonra uydurma hadisler, uyduranlar ve bu hususta basilan kitaplar üzerinde duran Rızaeddin Fahreddin, hadisçilerin bu tür rivayetleri diğerlerinden ayırdetme gayretleri ile hadis uydurma sebeplerini zikrettikten sonra, "son asır müelliflerinden biri" tarafından serdedilen şu görüşlere yer verir: “Kelbî”nin Tefsir'i, Mukatil b. Süleyman'ın kitabı ve Vakıdî Meğâzî̀si asılsızdır. Ebû Leys es-Semerkandî’nin Tenbîhu'l-Ğâfilîn adlı kitabında, Gazzâlî̀nin İhyâ'sında ve Hakîm-i Tirmizînin eserlerinde ve genel olarak tasavvuf kitaplarında bulunan hadislere -eğer başka tarikler ile sabit olmazlar iseitimad edilmez..." Ayrıca ismini vermediği bu kaynaktan, hangi konulardaki hadislerin uydurma olduğuna dair malumatı da aktarmaktadır. ${ }^{33}$

Uydurma oldukları belli olan rivayetleri bile bile nakl ve rivayet etmenin haram olduğunu belirten müellif, ilk zamanlarda Kazan'da pekçok defa basılan "Kırk Hadis" ve "Lübâb" ismindeki risalelerin büyük bir kısmının uydurma hadislerden ibaret olduğundan, bunların çocuklara ders kitabı olarak okutulmasını da münasip görmemektedir. ${ }^{34}$

\section{Rivayet ve Dirayet}

Hadis ilminin faziletine de değinen Rıza Fahreddin, sonra hadis rivayeti ile hadis dirayeti üzerinde durmaktadır. Hadis ilminin rivayet ilmi ve dirayet ilmi şeklinde ikiye ayırıldığını hatırlatan müellif, hadis usulü ve ıstılahlarına dair bahislerin, isnadlar ve raviler hakkındaki malumatın "hadis rivayeti" ya da "rivayet ilmi" kısmına girdiğini; isnadları sağlam olan hadislerle amelin mümkün olup olmadığının, "düsturu'l-amel" (davranış yasası) edinmek için herhangi bir engelin olup olmadığının teftiş edilmesinin ise "dirayet ilmi" kısmına girdiğini belirtmektedir. Ona göre, Rasûlullah Efendimiz Hazretlerinden nakledilen hadisle amel edebilmek için, onun sahih oldu- 
ğunu, cerh ve illetten salim olduğunu bilmek mecbur olduğu gibi; çoğu zaman onun içeriği ile amel etme hususunda ya şer'an, ya da aklen herhangi bir engelin olmadığının da bilinmesi gerekir. Zira her bir "Kale'n-Nebiyyu (a.s)" sözünün ardındaki ibare hadis olmadığı gibi; her bir hadis de "düsturu'l-amel" hükmünü almaz. İşte bu şeyleri tespit etmek, "hadis dirayeti" kısmını teşkil eder. Bundan dolayıdır ki, muteber hadis kitaplarından olan Buhârî ve Muslim'in Sahih'lerinde bulunan hadisleri İslam alimleri öylece kabul etmeyip, aksine hepsini teftiş etmişler, hatta bazı yerlerde metinlerde hatanın varlığını ispat etmişlerdir. ${ }^{35}$

\section{Hadis Öğretimi}

Hadis mualliminin dikkat etmesi gereken edeplerine değinen Riza Fahreddin'e göre, Hadis talebeleri ve hocalarının riayet etmesi gereken bazı edepler olduğu gibi, hadis şeyhleriyle dinleyicilerin de riayet etmeleri gereken edepler vardır. Talebelerin bunları bilmeleri ve onları kendileri için 'düsturu'l-amel' görmeleri gereklidir. Bu husustaki edepler hakkında İbnu'sSalah, Nevevî, Irâkî, İbn Hacer, Sehâvî ve Suyûtî gibi alimler güzel kitaplar telif etmişlerdir. Bu konudaki edepleri sıralamak yerine ictimâî edebe dair bir iki söz söyleyeceğiz:

$\mathrm{Bu}$ asırda ve bu memleketimizde hadis okutucuların, tarih ve coğrafya ilimleri ile beraber milletlerin hayat ve bekası ile ilgili meseleleri ve sosyoloji ile aşina olmaları lazımdır. Zira bu şeylerden haberi olmayan muallim, her türlü icat ve keşifleri işitip duran bugünkü talebelere Kur'an ve hadis-i şeriflerin âlî ilimlere de şamil olduğunu, dinin hem dünyevi, hem de uhrevî saadete kefil olduğunu anlatamaz. "Eza verecek şeyi yoldan def etmek, imandan bir şubedir"36 diye talebelere ders verdiği halde, bu hadisin işaret veya evleviyyet yolu ile delalet ettiği demir yolları açmak, durakları ve etrafını muntazam yapmak, köyleri yangınlardan korunacak şekilde planlı yapmak vb. şeyleri Rus ve frenklere has birşey zannedip, bunların İslam ile münasebeti olmadığına inanan muallimin hadis dersi okutmaya liyakatı yoktur. Yanlış telkin edilmiş talebeye göre, zihinleri boş olan talebeden daha az korkulur.

Kur'an ve Hadis derslerinde gönüllerine, şartlara ve zamana uygun gıdalar verilmediği, sosyal hayat, psikoloji gibi şeylerden bazı malumatlar verilmediği içindir ki, talebeler, Montesquieu, Wolter, Janacek Rosso ve Kant

35 A.g.e, s. 11-12.

36 “İman, yetmiş küsur şube olup, en faziletlisi 'Lâ ilâhe illallah' sözü, en hafifi de yoldan rahatsızlık veren şeyi atmaktır”. Müellif bu hadisi her ne kadar (Buhari, I. 8.) şeklinde göstermişse de, hadis bu lafzıyla Muslim, İman 58, I. 63; Ahmed, Musned, II. 379, 445'de yer almaktadır. 
gibi felsefecilerin makalelerini işittiklerinde hayran kalırlar da, İslam'da böyle yüce öğretilerin olmayışına üzülürler. Garip olan şudur ki, talebelerin cevâmiu'l-kelim (az sözle çok anlam ifade eden)hadisleri ve menâbiu'lhıkem (hikmet kaynakları) olan ayetleri bir tarafa koyup da, ikincilere sarılmalarına sebep olan muallim, bu hususta sırf kendisi mes'ul olduğu halde, talebeleri aşağılayıp kabahati onların üstüne atar.

Amerika hastahanelerinden birinde staj görmekte olan bir Hristiyan Arap doktorun, Arapça yazdığı bir kitabı okuduğumda "Keşke, bunun gibi alim bir zat, tefsir ve hadis dersleri okutup Kur'an ve hadislerin kemâlâtından talebeleri haberdâr etseydi!" diye gipta ettim. Zira onun söylediği malumat, tamamen İslam kaidelerine uygun idi. ${ }^{37}$

\section{Hadis Tarihi}

Hadislerin yazılması hakkındaki yasak ve izin konusunu ele alan Rızaeddin b. Fahreddin, hadis yazımına izin veren hadislerin bazı şahıslara ve bazı vakitlere mahsus olduğu halde, yazmaktan meneden hadislerin umumi olduğunu belirtir. Yasaklanmasının sebepleri üzerinde durduktan sonra, Mekke'de inen Kur'an surelerinin dahi şartların müsait olmaması sebebiyle ancak hicretten sonra Medine'de yazıldığını söylemektedir. Ona göre hadisleri yazma ve rivayetten men etme ile ilgili delillerin, hadislerin ezberlenmesi ile ilgisi yoktur ve ezberlemeden menedildiğine dair herhangi bir rivayet de bulunmamaktadır. İhtimaldir ki, hadisleri yazmaktan nehy, kişilerin yazıya itimad edip de ezberleme konusunda gevşeklik göstermemeleri sebebine mebnidir. ${ }^{38}$

"Hadis ve Tarih" başlığı altında, İslam dünyasında tarih ilminin ortaya çıkmasında birinci âmilin hadis ilmi ve onu ortaya koyan hadisçiler olduğu tespit edilmektedir. Zira onların, asr-1 saadette meydana gelen hadiselerin zamanını ve mekanını, hadisler arasındaki tabii ilişkileri tedvin edip ona göre hadislerden istifade etmeleri gerekiyordu. Bu sebeple onlar, nesep, rical ve cerh-tadil kaidelerini ortaya koydular. İşte bunun neticesi olarak muhaddisler, birçok kabile ve kavimlerin ictimai, siyasi ve iktisadi hallerini anlamaya muvaffak oldular. Böylece, Kur'an ve sünnet ilimleriyle birlikte tarih ilmi de ortaya çıkmıştır ve ilk defa tarih kitapları Ehl-i Hadis tarafından tertip edilmiştir. Buhârî, Taberî, Zehebî, Kelbî, İbn Asâkir, Belâzûrî, Vâkıdî, İbn Hacer, Suyûtî ve başkaları bu cümledendir. ${ }^{39}$ 
Asr-1 saadetten kısa süre sonra mütehassıs alimlerce, hadis kitaplarının tedvin edildiğini, isnadların zikredildiğini, cerh-tadil yapıldığını, sahih ile sakim olan hadislerin birbirinden ayrıldığını ileri süren müellife göre, "Artık Hadis alimleri nazarında sahih olanlarını sahih demekten ve onların fetvalarıyla amel etmekten başka çareye ihtiyaç kalmamıştır. Özellikle de, vasıtalar çoğalıp, asırlar ilerlemesi sebebiyle ravilerin hallerini bugün yeniden teftiş etmek, ya da meydanda olan Hadis kitaplarında yazılmış isnad zincirlerinden tamamen başka zincirler ve isnadlar bulup çıkarmak mümkün değildir". ${ }^{40}$ (s. 5)

\section{HADIS IMAMLARI VE ESERLERI}

Bu kısımda başta Kutub-i Sitte imamları olmak üzere meşhur Hadis imamla$\mathrm{r}$, onların eserleri ve bu eserler üzerine yazılmış olan önemli şerhler hakkında Rızaeddin Fahreddin'in mülahazaları verilecektir. Ağırlıklı olarak onun telif ettiği Kutub-i Sitte ve Müellifleri adlı eserinden nakledilecek bilgiler ve değerlendirmeler, hem müellifin birikimini ve bakışaçısını vermesi bakımından, hem de bazı ciddi katkılar sunması bakımından önemlidir.

Rizaeddin Fahreddin'e göre, Hadis ilminde Kutub-i Sitte en muteber ve mübarek eserler olduğu gibi, müellifleri de İslam aleminde en itimadlı ve en büyük zatlardır. Her ne kadar Muvatta, Buhârî ve Muslim'in Sahih'leri derecesinde değilse de ve cumhur bu kitabı Kutub-i Sitte arasına koymasa da, İmam Mâlik'in kendisi Kutub-i Sitte sahiplerine göre ittifakla önde gelir. Zira Kutub-i Sitte sahipleri İmam Mâlik'in talebelerinin telebeleridir. Bundan dolayı onu, ilk önce anlatmayı daha münasip görmüştür. ${ }^{41}$

Bazıları Sunen-i İbn Mâce yerine, İmam Mâlik'in Muvatta adlı eserini, bazıları ise Dârimî'nin Musned'ini saymışlardır. Fakat, Dârimî'nin Musned'i hakkında malumatımız olmadığından, nüshasının basılıp basılmadığını bilmediğimizden ve bugüne kadar mezkur kitabı görmediğimizden ondan bahsetme gücümüz yoktur. ${ }^{42}$

Kutub-i Sitte'den ilk ikisi "Sahîhayn”, kalan dördü "Sunen-i Erbaa”, İbn Mâce dışındaki beşi "Kutub-i Hamse" diye bilinir. Hem Buhârî, hem de Muslim tarafından rivayet edilen hadislere "Müttefakun aleyh" denilir. Sahih hadislerin tamamı Sahîhayn'da bulunmaz, zaten kendileri de bunu iltizam etmemişlerdir. Bundan dolayı başka Sahih kitaplar da vardır. Sahîh-i İbn Hıbbân, Sahîh-i İbn Huzeyme ve Hâkim'in el-Mustedrek'i gibi kitaplar bu cümledendir. Amma, Sahîhayn'da olan hadislerin her birinin kat'î olarak sahih-

40 A.g.e, s. 5.

41 A.g.e, s. 77.

42 A.g.e, s. 58. 
liğinin mümkün olup olmadığı konusunda ilim ehli arasında büyük bir tartışma vardır. ${ }^{43}$

Muhaddisler, hadislerin senedlerini araştırmışlar ve asılsız ya da isnadlı olup olmadıklarını tedkik ederek onları kendi kitaplarına yazmışlardır. Bundan dolayı bu günlerde, hadislerin isnadlarını, mecruh veya ta'nedilmiş olduklarını teftiş etmeye lüzum kalmamıştır. Belki elimizde olan itimad edilen eserlere isnad eylemek kafidir. Bunun içindir ki, "Kutub-i Sitte'nin birine isnad edilmiş hadis, güya bizzat Rasulullah hazretlerine isnad edilmiş gibidir" diyorlar. ${ }^{44}$

\section{A. Imam Mâlik ve Muvatta'ı}

İmam Mâlik 17 yaşından itibaren ilimle iştiğale başlamış ve bütün ömrünü bu yolda geçirmiştir. Hayatını neredeyse tamamen Rasûlullah'ın mescidinde geçirdiği, ahir ömründe ise kendi evine çekildiği, hatta cemaat ve Cuma namazlarına dahi çıkamadığı rivayet edilmiştir. Abbasilerin cebren aldıkları bey'atın bağlayıcı olmadığını söylediği için Medine valisi Cafer b. Süleyman tarafından kamçı ile dövülmesi sonucu kolu çıkmıştır.

İmam Mâlik hakkında İmam Şâfiî ile Muhammed eş-Şeybânî arasındaki, hangisinin hocasının daha alim olduğuna dair bir münazara neticesinde İmam Mâlik'in -kıyas hariç- Kur'an, Sünnet ve sahabe sözlerini bilmede Ebû Hanife'den daha alim olduğunu ortaya koyan menkıbevi bir rivayeti, sırf görmemiş demesinler diye naklettiğini belirten müellif, bu iki büyük imamın bu üslupta bir münazaraya girişmeyeceklerini, hikayenin mezhep taassubuyla böyle bir kalıba sokulmuş olduğu ihtimalini zikreder. ${ }^{45}$

Hem tarihçiler, hem de hadisçiler İmam Mâlik hakkında müstakil eserler telif etmişlerdir. ${ }^{46}$

İmam Mâlik bu kitabı, kırk yılda, 100.000 hadisten seçmiştir. İlim ehli, Muvatta'ı doğrudan nakledebilmek için cihanın dört tarafından İmam Mâlik'in huzuruna gelmiştir. Vasıtasız olarak ondan nakledenlerin sayısı binden fazladır. Bunlar arasında, İmam Şafii, Muhammed b. el-Hasen, İbn Vehb, İbnu'l-Kasım gibi meşhur fakihler, Yahya b. Said el-Kattan, Abdurrahman b.

43 Mezkur soruya tasdik ile cevap verenler, müttefakun aleyh olanlardan 52, yalnız Buhârî rivayetlerinden 68, Muslim rivayetlerinden 100 olmak üzere toplam 220 hadisi istisna ederler. Bkz: Suyûtî, Tedrîbu'r-râvî, s. 43.

44 Kutub-i Sitte ve Müellifleri, s. 31-32.

45 A.g.e, 79-80.

46 Ebû Bekr Ahmed b. Mervan el-Mâlikî ed-Dîneverî (ö. 310), Ebû'r-Ruh İsa b. Mes'ud eş-Şafî̂ (ö. 744) ve "Tezyînu'l-erâik bi menâkıbi Mâlik" adlı eseriyle Suyutî bu cümledendir. Müellif İmam Mâlik'in hayatı hakkında bilhassa İbn Abdilber'in Câmiu beyâni'l-ilm adlı eserinin Muhtasarı'ndan malum bilgileri nakleder. (s. 77-83) 
Mehdi, Abdurrazzak gibi hadis imamları, Harun er-Reşid, el-Emin ve elMe'mun gibi halifeler vardı. İmam Mâlik'in sağlığında Muvatta bütün İslam dünyasında meşhur olmuş ve nüshaları her bir vilayete gönderilmiştir.

İmam Şafii Muvatta hakkında: "Kur'an-1 Şerif'ten sonra en dürüst kitaptır" der. ${ }^{47}$ Kadî İyaz ise: "İslam aleminde Muvatta derecesinde insanların ilgisine mazhar olan bir kitap yoktur" der. Muvatta'nın bir başka üstünlüğü ise, muhaddisler arasında en sahih olmakla şöhret bulan isnadların çoğunu kapsamış olmasıdır.

Muvatta'nın birçok nüshaları vardır ve aralarında bazı farklar bulunduğu rivayet edilir. Günümüzde iki çeşit nüshası basılmıştır. ${ }^{48}$

\section{B. Imam Buhârî ve Sahîh'i}

Muhaddislerin şeyhi olan Buhârî, aslen Fâris kavmindendir. Babası İsmail b. İbrahim de hadis alimlerinden olup, İmam Mâlik ve Hammâd b. Zeyd gibi büyük zatlardan rivayet etmiştir. İmam Şafiî̀den hadis işitmişse de, Sahih'de ondan rivayeti yoktur. İki yerde geçen "İbn İdrîs" Şafiî değil, Abdullah el-Evdî el-Kufí'dir. Yezid b. Harun, Ebû Davud et-Tayalîsî ve Abdurrazzak'ın zamanlarına yetişmiş ise de, son zamanları olması hasebiyle onlardan doğrudan değil de vasita ile hadis nakletti.

"İman, söz ile amelden ibaret olup artar ve eksilir" görüşünde olan Buhârî, "Amel, imandan bir cüz değildir" itikadındaki kimselerin hadislerini yazmadı̆̆ını kendisi haber vermiştir. ${ }^{49}$

(Ümmetin yetmiş küsur fırkaya ayrılacağını bildiren) iftirak hadisinin aslının olup olmadığ $1,{ }^{50}$ olduğu takdirde sapık firkaların hangileri olacağını Makâlât ve Kelam ehillerine göre daha doğru anlaması lazım olan İmam Buhârî hazretlerinin Kelamcılar tarafından "fırka-i dâlle" diye hükmedilmiş mezheplere mensup muhaddislerden hadis tahsil ettiği malumdur. Haricilerin müctehidi olan Imran b. Hıttân ve başkalarının hadisleri Buhârî tarafından Sahih'de rivayet edilmiştir. ${ }^{51}$

47 İmam Şafii bu sözünü Süfyan-i Sevri'nin el-Cami'i, Hammad b. Seleme'nin el-Musannef'i gibi eserlerden üstün görmek kastıyla söylemiştir. Onun asrında Buhari ve Muslim'in Sahih'leri yok idi.

48 Biri, Yahya b. Yahya nüshası olup, 1280'de Tunus'ta ve Mısır'da, 1291'de Dehli'de, 1889'da Lahor'da basılmıştır. İkincisi ise, Muhammed b. el-Hasen eş-Şeybani nüshası olup, 1291'de Ludyanc'da Abdulhayy el-Leknevi'nin tashihi ile iki defa basılmıştır. 1909 tarihinde de, Maarif'in finansı ile Kazan'da basılmaya başlandı.(s. 74-75)

49 Kutub-i Sitte ve Müellifleri, s. 85.

50 İbn Hazm'a göre İftirak Hadisi isnad bakımından asla sahih değildir. Bkz: El-Fasl, III. 248.

51 Ebû Hanife Hazretleri Şia'dan Zeydiyye fırkasının müctehidi ve meşhur Vâsıl b. Atâ'nın talebesi olan İmam Zeyd b. Ali hazretlerinden itikad ve fikıh tahsil etti. Ayrıca Mutezile'nin reisi olan 
Buhârî̀nin hayatı, ilim tahsili, hocaları, menkıbelerinden örnekler, eserleri, şiirleri, bazı talebelerine tavsiyeleri gibi konulara giren müellif, "Vehimleri" başlı̆̆ 1 altında Buharî’nin bir hatasına işaret eder. Ne kadar büyük olursa olsun alimlerin masum olmadıklarını ve hataya düşmelerinin mümkün olduğunu belirten müellif misal olarak şunu zikreder:

(Buhârî'nin) 'kendi asrında mütedavel olan Tevrat'1, Kutub-i münezzeleden ve tevatür ile menkul olduğunu zannedip, bunun hakkında Kur'an-1 Şerif in söylediği tahrif ve tebdilleri, ancak tevil ve tefsire ait şeylerdedir' dediğini iddia ederler. ${ }^{52}$ Bu iddianın vehme dayandığında şüphe yok. Ellerindeki kitapların indirilmiş kitaplardan olduklarını Yahudi ve Hristiyanlar kendileri bile iddia etmemişler, belki onlara göre bu kitaplar Rasüller tarafından ilham ile yazılmıştır. Bunların tevatür ile nekledilip nakledilmediği hakkında da çok (farklı) görüşler vardır. ${ }^{53}$

'İmam Zuhlî ile Olan Macerası' başlığı altında ise, İmam Buhârînnin Nisabur'da hocası Zuhlî ile "Halku'l-Kur'an" ${ }^{4}$ meselesi yüzünden aralarının açılmasını anlatır. Zuhlî’nin "Bundan böyle Muhammed b. İsmail'e gidenlerle konuşmayız!" diye ilan etmesi üzerine Buhârî Nisabur'u terketmiş ise de, Zuhlî'den işittiği 30 aded hadisi Sahih'den çıartmamıştır. Ama "Bize Muhammed b. Yahya ez-Zuhlî rivayet etti" diyeceği yerde, sadece "Bize Muhammed rivayet etti" veya "Bize Muhammed b. Abdillah rivayet etti" diyerek yalnız ismini veya babasının ismi yerine dedesinin ismini zikretmekle yetinmiştir. ${ }^{55}$

"Son Günleri” başlığı altında ise şunları anlatır:

Buhârî, Nisabur'dan çıııp Buhara'ya dönerken başka bir felakete uğramıştır. Haddizatında âlim ve fâzıl bir zat olan Horasan valisi Halid b. Ahmed b. Halid ez-Zuhlî, Buhârî'den yalnızca kendi evlatlarına ders vermesi için onu öğretmen olarak tutmak üzere davet eder. Buhârî ise, ilmini sadece vali çocuklarına değil, umuma neşretme niyetinde olduğunu beyan ederek

Amr b. Ubeyd, Ehl-i Sünnet şeyhi olan Hasen-i Basrî huzurunda istifade eyledi. Bunların hiçbirinin, ikincisinin mezhebine taarruz ettiği rivayet edilmiş değildir. Kelam ehli ortaya çıkıp, şüphe ve şekler artmazdan evvel, Ehl-i İslam'ı tefrik etmezden evvel olan haller işbu minvalde devam etmiştir. Bkz: Kutub-i Sitte ve Müellifleri, s. 87.

52 El-Menar, VI. 87.

53 Fahreddin er-Razî, Tevrat'ın tevatür ile naklolduğunu ve tahriften maksudun da lafızlarını hakiki manalarından döndürmek olduğunu kabul etmiştir. Mefâtîhu'l-gayb, III. 236. İbn Hazm ise işbu sözü kesin bir şekilde reddetmektedir. El-Fasl, I. 215. Bkz: Kutub-i Sitte ve Müellifleri, s. 50.

$54 \mathrm{Bu}$ konunun iyice anlaşılabilmesi için bu vesile ile "Halku'l-Kur'an" Meselesi'ni hulasa etmiş ve konuyu "Mesele mühim olduğu kadar naziktir, gaflet olunmaya!" diyerek noktalamıştır. (s. 9598)

55 Kutub-i Sitte ve Müellifleri, s. 94. 
daveti reddeder. Bunun üzerine vali diğer alimleri ona karşı kışkırtmakla kalmaz ve sonunda onu Semerkant yakınlarındaki Hartenk kasabasına sürer. Buhara'daki dostları, akrabaları ve talebelerinin bile kendisiyle ilişkileri kesmeleri sebebiyle hayattan bezgin bir hale düşen Buhârî, H. 256 senesi Ramazan Bayramı gecesinde vefat etmiş ve Bayram'ın birinci günü Öğle namazından sonra Hartenk'te defnedilmiştir. ${ }^{56}$

Müellif, Sahîh-i Buharî’nin en muteber hadis kitabı olduğu yönündeki alimlerin ittifakını naklettikten sonra, ihtiva ettiği kitap, bab, hadis ve şeyh sayılarını verir, ${ }^{57}$ ardından Buharînnin muhtelif baskılarını zikreder. ${ }^{58}$

Buhârî̀nin matbu şerhlerine de değinen müellif, İbn Haldun'un, hocalarından "Buhârî’nin kitabını şerhetmek, ümmet üzerine bir borçtur" dediklerini nakleder. Bu söze karşı: "Belki de bu borç, İbn Hacer ve Aynî’nin şerhleriyle eda edilmiştir" diyen Kâtib Çelebînnin sözünü naklettikten sonra, bu şerhler hakkında muasırlarından bir kimsenin "İbn Hacer ile Aynî şerhleri, nakl ve hadisleri tatbik, tarihi vakıaları tafsil ve hüküm çıkarma cihetleriyle kamil iseler de, ictimaî haller ve bugünkü toplumların hayatına dair hususlarda şerhler noksan, belki bu hususlar hiç yoktur. Bunun için ümmet üzerinde olan borç henüz sakıt olmamıştır" dediğini aktarır. Daha sonra şu şerhler üzerinde durur:

1. Fethu'l-bârî: İbn Hacer (ö. 852) tarafından yapılan bu şerh, şerhler arasında en muteber olanıdır. İbn Hacer onu şerhetmeye 817'de başlamış, 842'de tamamlamıştır. Şarih bunu, zamanının büyük zatlarına verdiği bir davet meclisiyle kutlamıştır. Ayrıca nüshası 300 dinardan olmak üzere, şerhten birer nüsha gönderilerek etraftaki yöneticilere de duyurulmuştur. Şevkânî’nin, meşhur hadisin lafızlarını kullanarak "Lâ hicrete ba'de'l-Feth" (Mekke'nin fethinden sonra hicret yok) ${ }^{59}$ yani, "Fethu'l-bârî̀'den sonra başka bir şerh aramaya gerek yok" dediği işbu kitap ilk defa H. 1301'de Mısır'da basılmıştır. ${ }^{60}$

2. Umdetu'l-kârî: Bedreddin Aynî (ö. 855) tarafından kaleme alınan bu şerh ise 821'de başlamış, 847'de bitirilmiştir. Aynî, İbn Hacer'in şerhinin

56 Kutub-i Sitte ve Müellifleri, s. 99.

57 Müellif orada "Bu kitabı doğrudan doğruya müellifin kendisinden rivayet edenlerin 90.000 adede eriştiği" (s. 60-61) bilgisini nakleder ki, bu çok abartılı rakamın da ihtiyatla karşılanması gerekir.

58 Delhi, 1854, Mısır, 1862, Leiden, 1868, Bulak, 1879, Mısır, 1892, Bulak, 1895, İstanbul, 1897, Mısır, 1901 ve Mısır, 1902 baskıları içinde de en güzelinin Bulak, 1895 baskısı olduğunu söyler. (s. 61)

59 Buhârî, Menâkıbu'l-Ensâr 45, IV. 253, Cihad 1, 27, III. 200, 210; Ahmed, Musned, I. 226, 266, 355,469 , II. 215

60 Kutub-i Sitte ve Müellifleri, s. 62-63. 
nüshasını ödünç alarak ondan istifade eder, hatta bazı yerlerde uzunca nakillerde bulunurmuş. Bundan başka, Ruknuddîn el-Kırîmî (ö.783/1381) ${ }^{61}$ şerhinden de çok şeyler iktibas edermiş. Hatta Aynî şerhini medhedenlere İbn Hacer: "Aynî, Ruknuddin şerhinden istifade eder. Onun şerhi bittiğinde ise Aynî’nin sözlerinin azaldığını görürsünüz" demiștir. Zira Ruknuddin şerhi tamam değildir ve vakıa da İbn Hacer'in dediği gibidir. Aynî şerhi, kendisi hayatta iken, Fethu'l-bârî kadar şöhret bulmamıștır. Bunun sebepleri arasında, İbn Hacer şerhinden sonra tamamlanmasını, onun gibi büyük tanıtım meclislerinin yapılmamasını, Hanefilere göre Mısır'da Şâfilerin daha çok olmasını zikredebiliriz. Böyle de olsa, Aynî şerhinin de faydalı şerhlerden olduğunu alimler itiraf etmişlerdir.

Aslında İbn Hacer ile Aynî, ikisi de bir asırda, Mısır'da aynı bölgede yaşamışlar ve ikisi de Hadis ilminde ihtisaslaşmışlardı. Ayrı ayrı şerhler yazacakları yerde, ikisi birlikte yazmış olsalardı, şerhleri daha ziyade güzel ve faydalı olurdu. Fakat müslümanlarda iki-üç kişi birlikte kitap yazma âdeti olmamış, yahut nadir olmuştur. Bundan başka bu eserler, kendi talebelerine ders verme usulü ile yazılmış olduğundan bir iki kimsenin iştiraki mümkün olmamıştır. Bu şerh de H. 1309'da İstanbul'da 11 cilt olarak basılmıştır.

3. İrşâdu's-sârî: Müellifi Ahmed el-Kastallânî (ö. 933)'dir. H. 1267'de Bulak'ta basılmış olan bu şerh, haddizatında İbn Hacer'in Fethu'l-bârî'sinden alınmıştır, fakat isimler tashih edildiği için talebeler için faydalı olmuştur. ${ }^{62}$

4. Tuhfetu'l-bârî: Ebû Zekeriyya el-Ensârînnin (ö. 926) telifi olup matbudur.

5. en-Nûru's-sârî: Hasan el-Adevî'nin (ö. 1303) telifi olup basılmıştır.

6. Hâşiyetu's-Sindî: Ebû'l-Hasen el-Medenî es-Sindî'nin telifi olan bu eser de matbudur.

İslam dünyasında okuyup istifadeden ziyade, yazıp okutmaya rağbet çok olduğundan, Sahîh-i Buhârî üzerine yazılmış, şerh, haşiye ve taliklar pek

$61 \mathrm{Bu}$ zat, aslen Deşt-i Kıpçak başkenti olan Saray şehrindendir. İsmi, Ahmed b. Muhammed b. Abdulmümin olup, lakabı Ruknuddîn'dir. Mısır'a varıp Ezher Camii’nde ders verdi. “Ğarâibu'nnevâdir" ismindeki bu eserden istifade ettiğini Aynî itiraf edip "Sonra ben H. 800'den evvel Kuzey beldelerine seyahat ettiğimde orada bazı şeyhlerimizden Ğarâibu'n-Nevâdir'i elde ettim" demektedir. Bkz: Umdetu'l-kari, I. 2-3. Kahire, 1972; Kutub-i Sitte ve Müellifleri, s. 63'teki dipnot. Kırım Kadısı diye meşhurdur. Muhaddis, fakîh ve kadıdır. Otuz yıl Kırım'da kadılık yapmıştır. Hanefî fukahasındandır. Kırım'dan sonra Kahire'ye gitmiş, Ezher'de ders vermiştir. Oldukça başarılı geçen dersleri taassup sebebiyle reaksiyon görmüş ve küfrüne hamledilmiştir... Herşeye rağmen Buhari şerhi, ilmî ehliyetine delil teşkil edecek güzelliktedir. Eserini hazırlarken, İbnu'lMülakkin'in şerhinden yararlanmıștır. Bkz: İbnu'l-Imâd Abdulhay el-Hanbelî, Şezerâtu'z-zeheb, VI. 279, Beyrut, Daru'l-Afak el-Cedide; Sandıkçı Kemal, Sahih-i Buhari Üzerine Yapılan Çalışmalar, DİB Yay., Ankara, 1991, s. 37-38.

62 Kutub-i Sitte ve Müellifleri, s. 64-65. 
çok olup, ${ }^{63}$ Mısır ve Avrupa kütüphaneleri bunlarla doludur. Fakat ders verenler için İşâdu's-sârî; Hadis ilmine âşina olmak isteyenler için Fethu'lbârî; Hanefî mezhebine göre hadislerden hüküm çıkartmak hevesinde olanlar için Umdetu'l-kârî kafi olduğundan başka şerhlerden müstağni olmak mümkündür. Birbirinin nüshası kabilinden olan uzun şerhler, ömür kaybına ve çoğu zaman da ilim telefine neden olur. İbn Haldun kitapların çok olması$\mathrm{n} 1$ tahsil önündeki engellerden sayar. ${ }^{64}$

\section{Imam Muslim ve Sahîh'i}

İmam Muslim'in hayatını ve hocalarını anlatan müellif, Nisabur'a geldiğinde onun Buharî'den de hadis tahsil ettiğini, ancak Sahih'de ondan rivayeti bulunmadığını belirtir. Buhârî'ye olan muhabbet ve ihlası sebebiyle Zuhlî̀nin meclisinden ayrıldığ 1 ve ömrü boyunca ondan işttiği hadisleri, bir hamala yükleyip iade ettiği rivayet edilir.

Daha sonra "İmam Muslim Şafiî mezhebinde olup, bu doğrultuda selabetliydi, Şafiî mezhebine muhalefet etmez ve mümkün mertebe onu himaye ederdi. Ama Buhârî, Şafiî olsa da, birçok yerde ona muhalefet eder" dedikten sonra şu notu düşer:

"Bu söz Şafiî alimlerin eserlerinden alındı. Onlar ise, bütün dünya alimlerini Şafiî göstermeye gayret ettikleri cihetle, sözlerine teslim olmak zordur. Buhârî ve Muslim gibi zatların mezhepleri taklid ettikleri kendilerinden ikrar ve tasrih olunmadığ surette tasdik edilmez". ${ }^{65}$

Bütün alimler, tertip cihetiyle Muslim'in; isnadlarının sağlamlı̆̆ı cihetiyle de Buhârî̀nin Sahih'inin daha güzel olduğunda ittifak etmiştir.

Muhaddisler, teftiş ettikten sonra Sahîh-i Muslim'deki işbu hadislerde galat olduğunu bildirmişlerdir:

1. Rasulullah'ın Küsuf namazını üç rüku ile kıldırdığını bildiren hadis, ${ }^{66}$

2. Allah'ın toprağı da Cumartesi günü yarattığını zikreden hadis ${ }^{67}$

3. Ebû Sufyan'ın Müslüman olduktan sonra, kızı Ummu Habîbe'yi Rasulullah'a vermesi hakkındaki hadis. ${ }^{68}$ Fakat bunlar gayet az olup, amele dair de değildir. ${ }^{69}$

63 Bu konuda bkz: Sandıkçı Kemal, a.g.e.

64 Kutub-i Sitte ve Müellifleri, s. 65.

65 Kutub-i Sitte ve Müellifleri, s. 101, 1. dipnot. Muslim'in eserleri arasında "Kitabu'l-Vicdan" şeklinde bir eser zikredilmiștir ki, bu bir matbaa hatası olsa gerektir. Zira doğrusu "Kitabu'l-Vühdan" olmalıdır ve eser bu isimle günümüzde basılmış haldedir.

66 Muslim, Kusûf 1-11, I. 618-624.

67 Muslim, Sifatu'l-Munafikîn 27, III. 2149-2150; Ahmed, Musned, II. 327.

68 Muslim, Fedâilu's-Sahâbe 168, II. 1945.

69 Ayrıca "Nahnu necîu yevme'l-Kıyâmeti 'an kezâ ve kezâ unzur!" hadisinde de (Muslim, İman 
Sahîh-i Muslim'in 1849-Kalkuta, 1873-Bulak, 1909-Mısır baskılarını, şerh olarak Nevevî (ö. 676) şerhini, fihrist olarak da yine et-Tokâdî’nin 52 sayfalık matbu eserini zikreder. (s. 68-9)

\section{Imam Ebî Dâvud ve Sunen' $i$}

Ebû İshak eş-Şîrâzî, Tabakâtu'l-Fukahâ adlı kitabında Ebû Dâvud'u, Ahmed b. Hanbel'in ashabından addetmiştir. Ebû Amir adlı zamanın emiri, kendi çocuklarına ayrıca ders vermesini teklif ettiğinde: "Bu iş olmaz, ilim hususunda emirlik veya avamlık yoktur!" demiştir. ${ }^{70}$

Kutub-i Sitte'nin üçüncüsü olan bu kitap, fikhî hadisleri toplaması cihetiyle bazı alimler tarafından Sahîhayn'dan bile üstün görülmüştür. İbnu'lA'râbî "Elinde Kur'an ile Sunen-i Ebî Davud olan kimse her kitaptan müstağnidir" demiştir. Ebû Davud kitabını tertip ettikten sonra, Ahmed b. Hanbel Hazretlerine göstermiş, o da bunu güzel bulmuştur. İmam Gazzâlî ise, müctehidler için Sunen-i Ebî Davud'un kafi geleceğini söylemiş, Şâfiî alimlerden çoğu da buna muvafakat etmiş̧ir. Ebû Davud ile Tirmizî hakkında: "Her ikisi de mutlak müctehid idiler. Fakat zahirde biri Ahmed, diğeri ise İshak b. Râhûye mezhebine mensup göründüler" diyorlar.

Sunen-i Ebî Davud ilk defa 1280'de Misır'da, ikinci kez 1283'te Dehli'de basılmıştır. Bu asrın başında vefat eden Ali ed-Dimnâtî tarafından yazılmış ve 1298 'de Mısır'da basılmış "Derecâtu Mirkâti's-Suûd" adlı bir şerhi vardir. ${ }^{71}$

\section{E. İmam Nesâî ve el-Muctebâ'sı/Sunen'i}

Hafızasının kuvvetli oluşunda Nesâî'yi Muslim'e tercih ederler. "Cerh-tadil hakkında İmam Nesâînin sözleri makbul ve şehadeti muteberdir" derler. Şafiî mezhebine mensup idi. Menâsiku'l-Hac kitabını da buna binaen yazdı$\breve{g} 1$ rivayet edilir. Mısır'da yaşadığı için yazdığı kitaplar da orada yayıldı. H. 302 tarihinde Şam'a gitti. Orada Hz. Ali ve Ehl-i Beyt hakkında "el-Hasâis" adlı bir eser yazdı ve Şamlıların tepkisini çekti. Muaviye'nin faziletine dair hadisler rivayet etmesini istediklerinde, buna olumsuz cevap vermesi üzerine Muaviye taraftarları ona hücum etmişler ve bunun tesiri ile de vefat et-

316, I. 177) tashif edilmiş diyorlar. Güya doğrusu: "Nahnu necîu yevme'l-Kiyâmeti 'alâ kûm" olup (Bkz: Ahmed, Musned, III. 345), 'kûm' sözü, 'kezâ' şeklinde yazılmış da manasını anlamamış bir kişi, haşiyeye "aslında şöyle teftiş kıl!" manasında olan 'kezâ unzur!' diye yazmış, sonra da bu söz metin olarak nakledilmiştir.

70 Kutub-i Sitte ve Müellifleri, s. 102.

71 A.g.e, s. 69-70. 
miştir. Bir rivayete göre vefat etmezden evvel kendisinin ricası ile akrabalar1 onu Mekke'ye götürmüşler ve Safâ ile Merve arasına defnetmişlerdir. ${ }^{72}$

İmam Nesâî ilk önce es-Sunen el-Kubrâ adlı büyük bir Hadis kitabı tertip etmiş sonra da bunu ihtisar ederek yeni bir seçki yapmış ve ona da "el-Müctebâ" adını vermiştir. Bazıları bunu "el-Müctenâ" diye de yazarlar. İşte Kutub-i Sitte'den addedilen eser el-Müctebâ'dır. Bu kitabın mertebesinin Sahihayn'dan sonra geldiğini söyleyenler olmuş, hatta Mağrib alimlerinden bazıları onu Buhârî’nin Sahih'inden daha önde tutmuşlardır. Kutub-i Sitte içerisinde sadece bu kitapta Ebû Hanife'den bir hadis rivayet edilmiştir. ${ }^{73}$

\section{F. Imam Tirmizî ve Cami'i}

Buhârî ile birlikte tahsile başlamış, ancak sonradan ona talebe olmuş ve ondan istifade etmiştir. Ahmed b. Hanbel ile İshak b. Râheveyh mezheplerine nisbet edilmiş ise de, doğrusu, hiçbirinin mezhebine tabi olmadığı ve kendisinin mutlak müctehid olduğudur. Ahir ömründe gözleri görmez olduğu halde hizmete devam etmiştir. ${ }^{74}$

İmam Tirmizi bu kitabını telif ettikten sonra Hicaz Irak ve Horosan alimlerine arz etmiş ve onların övgülerini almıştır. Tertibi güzel, tekrarları az, istidlal yönlerini ashab ve tabiinin görüşlerini isimlerinde şüphe bulunan ravilerin künyelerini beyan ettiğinden bu kitap, Sünen kitapları arasında en fazla istifade edilenidir. Şeyhulislam Ebû İsmail Abdullah el-İsbahani "Benim nazarımda bu kitap Buhârî ile Muslim Sahihlerine göre daha faydalıdır" demiştir. Bununla birlikte bazı hadisleri tenkid edilmiştir. ${ }^{75}$

1844 ve 1849 'da Dehli'de taşbasma olarak, 1292 'de ise Bulak'da bas1lan eserin Ali ed-Dimnatî tarafından yapılan Nef'u Kûti'l-Muğtezî adlı Dehli baskısı bir şerhi vardır. ${ }^{76}$

72 Kutub-i Sitte ve Müellifleri, s. 103-104.

73 Yaptı̆̆ımız araştırmada, Nesai'de Ebu Hanife'den nakledilmiş her hangi bir rivayete rastlanmamıştır. Ancak, Menasik 77, V. 179'daki bir isnadda Abdulvaris b. Ebi Hanife ismi geçmektedir. Müellif muhtemelen bu isimle karıştırmış olmalıdır.

74 A.g.e, s. 105

75 İbnu'l-Kayyim: Rasul-i Ekrem ile Ebû Talib'in Şam Yolculuğu hakkındaki uzun hadiste (Tirmizi, II. 203) yer alan "Onunla birlikte Ebû Bekir ve Bilal'i gönderdi” cümlesi hakkında: "Bu açı bir hatadır. Çünkü belki de Bilal o zaman yoktu!” der. (Zadu'l-maad, I. 17). İbn Teymiye de "Ben ilim şehriyim Ali de onun kapısıdır" hadisi hakkında "Yalan" diyor. (el-Mecmuatu'l-kubra 337). İmam Tirmizi Menakıb-i Ali bahsinde "Ben hikmet eviyim. Ali de onun kapısıdır" diye bir hadis nakleder. (II. 214) İbn Teymiye'nin muradı işbu hadis midir acaba?

76 Kutub-i Sitte ve Müellifleri, s. 71-72. 


\section{G. Ibn Mâce ve Sunen'i}

Meşhur müfessir, hafız ve muhaddislerden olan İbn Mâce, H. 209 tarihinde Kazvin şehrinde dünyaya gelmiştir. Kazvin Tarihi ve başka eserleri vardır. $\mathrm{H}$. 273 Ramazan'ında 64 yaşında vefat etmiştir. ${ }^{77}$

Bu eseri ilk defa Kütüb-ü Sitte'nin altıncı kitabı olarak sayan el-Fadl b. Tahir el-Makdisî olmuştur. Mecduddin İbnu'l-Esir ise: “İbn Mace'nin Sünen'i fikıh nazarından faydalı bir eser olsa da sıhhat bakımından hadisleri Kutub-i Hamse derecesinde değildir." Hatta o, "Onda münker hadisler var" diyerek bunun yerine el-Muvatta'yı altıncı kitap olarak sayar. İbn Mace'nin Kazvin'in fazileti hakkında rivayet ettiği hadise ${ }^{78}$ uydurma diyorlar. Ayrıca ayakta bevletmeyi yasaklayan Cabir hadisi hakkında da muhaddisler büyük tartışmalar yapmışlardır. ${ }^{79}$

\section{H. Ebû Hanîfe}

Meşhur müctehidlerden söz eden müellif, İbn Haldun'un 'Ebû Hanife'nin rivayetleri, on yedi kadar hadise ulaştı" dediğini naklettikten sonra, "Bu ibarede bazı kelimeler düşmüş olsa gerektir. Zira Ebû Hanife her ne kadar başka muhaddisler kabilinden Horasan, Misır, Yemen ve Nisabur gibi yerlere gitmemiş ise de, büyük alimlerden ve müctehidlerden olduğunda şüphe yok. Böyle bir müctehid için on yedi aded hadis az olsa gerek... Ne gibi bir kelimenin düştüğünü tayin etmeye gücümüz olmasa da, İbn Haldun'un bu ibaresinde ğalat olduğunda şüphemiz yoktur. Bu ğalat ise, İbn Haldun'un kendisinde değil, belki de, müstensihler tarafından meydana gelmiş olur. Ebû Hanife'nin rivayetlerinin az olması, sadece başkalarına göredir. Bunun yanısıra, Ebû Hanife tarafindan rivayet edilmiş hadisler, sonraki alimler tarafından "Müsned-i Ebî Hanîfe" adıyla kitap şeklinde tertip edilip neşredilmiştir. Gördüğümüz bir nüshadaki hadisler on yedi değil, belki yüzlercedir. Bazıları, "Hadis rivayetinde Ebû Hanife'nin şartları pek ağır idi, bu nedenle başkalarına göre hadisi az oldu" dese de, aslında Buhârînnin şart-

77 Kutub-i Sitte ve Müellifleri, s. 105-106.

78 İbn Mâce, Cihâd 11, no: 2780, II. 929. Bkz: İbnu'l-Cevzî, el-Mevdûât, II. 56.

79 İbn Mace, Tahare 14, no: 309, I. 112'de "Cabir (r)'den naklettiği: Rasulullah (s) ayakta bevletmeyi yasakladı" hadisinin şerhinde Neylu'l-evtar sahibi (Şevkani): "İsnadında Adiyy b. el-Fadl olup, kendisi metruktür. Hafız (İbn Hacer?)'in dediklerinden de anladığın gibi, Rasulullah (s)'ın ayakta bevletmekten yasakladığına dair sabit bir şey yoktur." demektedir. İşbu bahiste İbnu'lKayyim Zadu'l-maad adlı eserinde: "Rasulullah (s)'dan hem ayakta, hem de oturarak bevletme sabit olmuştur ve hepsi sünnettir." diyor. Bunlar ise İbn Mace'nin rivayetine eleştiridir. Kazvin hadisi hakkında Zehebi, Mizanu'l-i'tidal'de (I. 224): "İbn Mace bu uydurma hadisi Sünen'ine almakla ayıp etmiştir!" der. 
larına göre hafif idi. Fakat bir müctehid için, kendisine gereken kadar hadis rivayet etmesi kafidir. ${ }^{80}$

\section{i. Diğer Hadis Kaynakları}

Fetihlerle birlikte sahabenin önce çeşitli bölgelere dağılması, sonra da vefat etmelerinin ardından Hadis kitaplarının tedvin edilmeye başlanmasından söz edilmektedir. H. II. asırda ilk tedvin edilen eserleri müellifleriyle birlikte zikrettikten sonra hadisçiler tarafından tedvin ve tasnif edilen başlıca müsnedleri saymaktadır. İbn Rahûye, Tayalîsî, Bakıy b. Mahled, Ahmed b. Hanbel'in müsnedlerinin yanısıra İmam Ebû Hanîfe ve Şafiî̀nin müsnedlerini de burada kaydeder. Ayrıca o, hadis lügatları hakkında genel malumat vermektedir. Ebû Ubeyde Ma'mer b. el-Müsennâ (ö. 210) ve Nadr b. Şümeyl (ö. 204)'i zikrettikten sonra, Ebû Ubeyd Kasım b. Sellâm'ın (ö. 224) kırk yılda tertip ettiği eserini bu sahanın "en mükemmeli ve güzeli" diye nitelendirir. Ancak bugün halk için en faydalı olan çalışmanın İbnu'lEsîr'in (ö. 606) "en-Nihâye fí ğarîbi'l-hadîs" adlı eseri olduğunu vurgular. ${ }^{81}$

Rical isimleri hakkında telif edilen matbu kitapları saymaktadır. Ashab-1 Kiram ve büyük muhaddislerin isim ve künyelerini, lakab ve kabilelerini, asır ve şöhretlerini, doğum ve vefat tarihlerini bilmek hadis ilmiyle meşgul olanlar için herşeyden evvel zaruridir. Hatta "Hadis ravileri hakkında kafi derecede malumat edinmemiş bir kimsenin kendisini hadis ilmine intisab etmeye hakkı yoktur" demişlerdir. Zira bu isimler hakkında malumatı olmayan kişiler, künye ve lakabları görmekle birçok yanlışlıklara düşer.

Sahabe biyografileri hakkında İbn Abdilberr'in (ö. 463) el-Istîâb fì ma'rifeti'l-ashâb; İbnu'l-Esîr'in (ö. 630) Usdu'l-ğâbe fî ma'rifeti's-sahâbe; İbn Hacer'in (ö. 852) el-İsâbe fí temyîzi esmâi's-sahâbe ${ }^{82}$ ile ed-Dûlâbî̀nin (ö. 310) el-Kunâ ve'l-esmâ adll eserlerini zikretmektedir.

Raviler hakkında basılan kitaplardan da, Zehebî’nin (ö. 748) Tezkiratu'lhuffâz, Tabakâtu'l-huffâz, el-Muștebeh ve Mîzânu'l-i'tidâl adlı eserleri ile; Safiyyuddîn el-Hazrecînnin, Hulâsatu tehzîbi'l-kemâl adlı eserini kaydetmektedir. ${ }^{83}$

Ayrıca Hadis Usulüne dair basılan sekiz kitabı, müellifleri ve basım yıl ve yerleri ile birlikte sıralamaktadır. ${ }^{84}$

80 Kutub-i Sitte ve Müellifleri, s. 17-18.

81 Kutub-i Sitte ve Müellifleri, s. 44.

82 Ancak müellif burada el-İsâbe'de verilen sahabe isimlerinin 80.000 mikdarında olduğunu kaydetmektedir ki bugünkü matbu ve rakamlı baskılarında 12. 295 isim bulunmaktadır. Muhtemelen müellif adı geçen kitaptaki tekrarları çıkartarak belki de 8.000 isimden söz etmekteyken, matbaa hatası sonucu 80.000 olarak yazılmıştır.

83 Kutub-i Sitte ve Müellifleri, s. 48-50.

84 A.g.e, s. 12. 


\section{J. Kutub-i Sitte (Ille Ilgili) Mecmualar}

Mükerrer hadisleri çıkartmak ve tertiplerini değiştirmek, kısaltmak, Kutubi Sitte'nin bazılarını veya tamamını biraraya getirmek şeklinde çeşitli telifler arasında şunlar maruftur:

\section{1. el-Cem' beyne's-sahîhayn:}

a. Ebû Abdullah Muhammed b. Ebî Nasr el-Humeydî (ö. 488): Bunun üzerine birkaç şerh ve haşiye yazılmıştır.

b. Ebû Muhammed Huseyn b. Mes'ud el-Beğavî (ö. 516),

c. Ebû Bekr Muhammed b. Abdullah en-Nisaburî (ö. 388),

d. Ebû Muhammed Abdulhakk b. Abdurrahman el-Işsilî (ö. 582),

e. Ebû Muhammed İsmail b. Ahmed b. el-Furat es-Serahsî el-Herevî (ö. 414),

f. Ebû Cafer Ahmed b. Muhammed el-Kurtubî b. Ebî Hucce (ö. 642),

g. Ebû Bekr Ahmed b. Muhammed el-Burkânî (ö. 425),

h. Ebû Mes'ud İbrahim b. Muhammed b. Ubeyd ed-Dimeşkî (ö. 401),

1. Ebû's-Seâddât b. el-Esîr (ö. 606).

2. Tecrîdu's-sihahi's-sitt: Ebû'l-Hasen Razîn b. Muaviye el-Abderî es-Serekatsî (ö. 535) tarafından Muvatta ile birlikte, İbn Mace hariç Kutub-i Sitte bir araya getirilmiştir.

3. Câmiu'l-usûl li ahâdîsi'r-Resûl: Ebû's-Seâddât Mecduddin b. elEsîr (ö. 606) tarafından Rezîn'in "Tecrîdu's-Sihahi's-Sitt" adlı kitabı ile birlikte Kütüb-ü Sitte tertip edilmiştir. Buhârî ve Muslim'in ibarelerine itibar edilmiştir. Birçok zat tarafından ihtisar edildiği rivayet edilmektedir.

4.Câmiu'l-mesânîd: İbn Kesîr (ö. 774) tarafından tertip edilen bu kitapta Kütüb-ü Sitte ile beraber dört Musned biraraya getirilmiştir.

5.Cem'u'l-cevâmi': Suyutî (ö. 911) tarafından bütün hadis kitapları biraraya gertirilerek tertip edilmiştir. Tamamlayamadan vefat ettiği için ve yeniden gözden geçirilmesi gerektiği için bu kitapta zayıf hatta uydurma hadislerin bulunduğu rivayet edilmektedir. Muttakî Alauddin Ali b. Husamuddin el-Hindî (ö. 975) bu kitabı "Kenzu'l-ummâl fì suneni'l-akvâli ve'lef'âl" ismi ile yeniden tertip etmiştir. ${ }^{85}$

\section{K. Hadis IIminde Itimad Edilen Imamlar ve Vefat Yılları}

Hadis ilminde Kutub-i Sitte ve müelliflerinden başka hadisleri ve kitapları kabul gören birkaç muteber imam daha vardır:

1. Ebû Muhammed Abdullah b. Abdurrahman es-Semerkandî ed-Dârimî (ö. 255)

85 A.g.e, s. 107-108. 
2. Ebû Bekr Ahmed b. Amr el-Basrî el-Bezzâr (ö. 292)

3. Ebû Ya'lâ Ahmed b. Ali el-Mevsılî (ö. 307)

4. Ebû Bekr Muhammed b. İshak b. Huzeyme en-Nisaburî (ö. 311)

5. Ebû Avane Yakub b. İshak el-İsferayînî en-Nisaburî (ö. 316)

6. Ebû Cafer Ahmed b. Selame el-Ezdî el-Mırrî et-Tahâvî (ö. 321)

7. Ebû Hatim Muhammed b. Hibban b. Ahmed el-Bustî İbn Hibbân (ö. 354)

8. Ebû'l-Kâsım Süleyman b. Ahmed et-Tabarânî (ö. 360)

9. Ebû Ahmed Abdullah el-Curcânî ibn Adiyy (ö. 360)

10. Ebû Bekr Ahmed b. Muhammed ed-Dîneverî İbnu's-Sunnî (ö. 364)

11. Ebû'l-Hasen Ali b. Ömer ed-Dârekutnî (ö. 385)

12. Ebû Nuaym Ahmed b. Abdullah el-Isbahânî (ö. 430)

13. Ebû Abdullah Muhammed b. Abdullah en-Neysâbûrî el-Hâkim (ö. 405)

14. Ebû Muhammed Abdulğanî b. Saîd el-Misrî el-Ezdî (ö. 409)

15. Ebû Bekr Ahmed b. el-Huseyn el-Beyhakî (ö. 458)

16. Ebû Omer Yusuf b. Abdullah en-Nimerî el-Kurtubî İbn Abdilberr (ö. 463)

17. Ebû Bekr Ahmed b. Ali el-Bağdâdî İbnu'l-Hatîb (ö. 463) ${ }^{86}$

L. Kutub-i Sitte'den Başka Matbu Hadis Kitapları

Müellif elinde bulunan kitap listesi şeklindeki bir defterden hareketle şu kitapları sıralamaktadır:

el-ìthâfâtu's-seniyye fi'l-ahâdîsi'l-kudsiyye-Şeyh Muhammed elMedenî,

Ahsenu'l-hadîs-Türkiye alimlerinden Okçuzâde'nin bu eseri 40 hadis şerhi olup 1313'te İstanbul'da basılmıştır.

el-Erbaûne hadîsen-Nevevî, Hindistan, Misır, İstanbul, Kazan ve Petersburg'da defalarca basılmıştır. Şu şerhleri vardır:

a. el-Fethu'l-mubîn-İbn Hacer el-Mekkî (Mısır-1307).

b. el-Futuhâtu'l-vehbiyye-İbrahim Merî̀ eş-Şibrhaytî (Misır-1304).

c. el-Mecâlisu's-seniyye-Ahmed b. Hicâr el-Fişenî (Misır-1299 ve1303).

el-Erbaûne hadîsen-İsmail Hakkı'nın eseri olup Ali Hafız el-Kastomonî şerhi ile birlikte İstanbul-1303'te basılmıştır.

Bulûğu'l-merâm min ahâdîsi’l-ahkâm-i̇bn Hacer el-Askalânî'nin bu eseri Ebû'l-Hayr Nur el-Hasen el-Huseynî el-Kannûcî el-Buhârî şerhiyle birlikte Mısır-1302'de iki cild halinde basıldı. Muhterem Musa Carullah Efendi 
tarafından yazılmış olan "İfâdâtu'l-kirâm" adlı şerh de Kazan'da "Hârîtûn" matbaasında basılmaya başlandığı adımıza gelen iki-üç formasından anlaş1ldı. "İfâdâtu'l-kirâm" ilmi bir üslup ile yazıldığından güzel bir eser olacağına ümidimiz kamildir. ${ }^{87}$

Bin Bir Hadis-i Şerif Şerhi-Mehmed Arif Bey tarafından el-Câmiu'ssağîr' den seçilen hadisler Türkçe şerhedilerek 1319'da 460 sayfa olarak M1sır'da, sadece metni ile 1327'de Kazan'da basildı.

et-Terğ̣̂̉b ve't-terhîb-Zekiyyuddin el-Munzirî. Misır-1324'de iki cild olarak basildi.

Teysîru'l-vusûl ilâ ma'rifeti'l-vusûl-İbnu'd-Deyba'. İbnu'l-Esîr'in Câmiu'l-Usûl adlı eserinden ihtisar etmiş ve Kalkuta-1253'te basılmıştır.

el-Câmiu's-sağîr fî hadîsi'l-beşîri'n-nezîr-Suyûtî'nin bu eseri Bulak-1286'da iki cilt ve Misır-1325'te üç cild halinde basıldı. Hamişinde de şu iki şerh beraber basılmıştır:

a. es-Sirâcu'l-munîr fî şerhi'l-câmii's-sağîr.

b. Şerhu'l-Hanefî.

Suyûtî̀nin bu eserinde pekçok mevzu hadisler dercettiği iddia edilmektedir. Onun için bu kitabın Hadis kitabı olarak değil de, Hadis Fihristi olarak kullanmak gerekir. ${ }^{88}$

Cevâmiu'l-kelim-Rızaeddin b. Fahreddin, Kazan, 1911, s. 32.

el-Cevâhiru'l-munîfe fî edilleti'l-imam Ebî Hanîfe-Seyyid Murtazâ ez-Zebîdî. İskenderiye, 1292'de iki cild olarak basılmıştır.

Râmûz el-ahâdîs-Ahmed Ziyâuddîn el-Gümüşhânevî. Kazan, 1307'de 468 sayfa olarak basılmıştır. Levâmiu'l-ukû ${ }^{89}$ adlı şerhi ise İstanbul'da basılmıştır.

el-Kavlu'l-musedded alâ musnedi'l-imam Ahmed-İbn Hacer elAskalânî. Haydarâbâd'da basıldı.

Kenzu'l-ummâl fí suneni'l-akvâli ve'l-ahvâl-Ali el-Muttakî tarafından ihtisar edilmiş olan bu eser Haydarâbâd-Deken'de ve Ahmed b. Hanbel'in Musned'inin hamişinde de Mısır'da basıldı.

87 Maalesef bu eserin basımının gerçekleştirildiği bilinmemektedir.

88 Yazar burada muasırlarından Muhammed Bedruddîn el-Halabî'nin et-Ta'lîm ve’l-irşâd, I, 92 92'ten bir paragraflık bir değerlendirme nakletmektedir. Orada hangi daldan olursa olsun Suyûtî'nin güzel gördügüu her kitabı ihtisar ettiği ve sahih ile zayıfı ayırtedemediği, o eserin müellifinin görüşü dışına çıkamadığı, el-Câmiu's-sağîr'deki birçok hadisi el-Leâliu'l-masnûa adlı eserinde de naklettiği ve uydurma hadisler olduğunu belirttiğini, kendisinin telif yapmadığını ve başkalarının kitaplarını ihtisar ederek kendine nispet ettiğini söylemektedir. Kutub-i Sitte ve Müellifleri, s. 112.

89 Müellif bu şerhin ismini Levâmiu'l-beyyinât şeklinde vermiştir. Oysa eser, Levâmiu'l-ukûl adıyla İstanbul, 1292'debasılmıştır. Bkz: İrfan Gündüz, "Gümüşhanevî" DİA, XIV, 277. 
Kunûzu'l-hakâik fị hadîsi hayri'l-halâik-Munâvî tarafından 10.000 hadis seçilerek tertip edilmiş ve basılmıștır.

Mebâriku'l-ezhâr şerhu meşâriku'l-envâr-İbn Melek'in telifi olan bu eser metniyle beraber Mısır'da bir cild olarak basılmıştır.

Musnedu Ebî Hanîfe el-İmam el-A'zam- Muhammed Abid el-Medenî es-Sindî. Leknev'de 373 sayfa halinde taşbaskı yapıldı. Aynı isimle Ebû'lMueyyed Muhammed b. Mahmud el-Havârezmî (ö. 665) tarafından telif edilmiş ikinci bir eser de Misır-1326'dabasıldı.

Musned-Ebî Dâvud et-Tayâlîsî. Haydarâbâd-Deken'de bir cild halinde basild1.

Musned-Ahmed b. Hanbel. Misır-1303.

Mişkâtu'l-mesâbîh-Veliyyuddîn el-Hatîb'in eseri olan kitap Kalkuta1259'da dört cild olarak Petersburg-1899'da ise ikişer cild olarak basıldı. Matbu şerhleri şunlardır:

a. Eşi'atu'l-lemeât-Metni ile beraber Kalkuta baskısında neşredildi.

b. Mirkâtu'l-mefâtîh-Aliyyu'l-Kârî. Mısır-1309'da beş cilt olarak basıldı.

Mişkât'ın bugünlerde Kazan'da da basılmakta olduğunu işittim.

Mesâbîhu's-sunne-Beğavî'nin bu eseri tahminen 4719 hadis içermektedir. Bulak-1294'te iki cild olarak basılmıştır. ${ }^{90}$

Maâni'l-âsâr- İmam Tahâvî. Leknahor-1302'de iki cild halinde taşbask1 yapild1.

el-Mu'tasar mine'l-muntahab min muşkili'l-âsâr-Kâdî Ebû'lMehâsin Yusuf b. Musa el-Hanefî tarafından telif edilen bu eser Haydarâbâd-Deken'de bir cilt halinde basıldı.

Munteka'l-ahbâr fi'l-ahkâm-Mecduddîn İbn Teymiyye. Şevkânî’nin Neylu'l-evtâr adlı şerhi ile birlikte Mısır-1297'de 8 cild halinde basılmıştır.

Hadis ilimlerinde bunlardan başka bilmediğimiz daha çok kitaplar bulunmakla birlikte bizim bildiklerimiz bunlardır. Burada zikredilen kitapların hiçbiri Kutub-i Sitte derecesinde değildir. Onlar içinde de en muteberleri Ahmed b. Hanbel'in Musned'i, Tayâlîsî'nin Musned'i, Nevevî, İbn Hacer ve Mecduddîn İbn Teymiye'nin eserleri olsa gerek.

Muasırlarımızdan birisi Suyûtî̀nin el-Câmiu's-sağîir adlı eseri ve onun muhtasarlarının zayıf hatta uydurma hadisleri kapsadığını, onun hadislerini Ehl-i Hadis'in yöntemiyle tahric ederek şimdiye kadar şerheden birinin çıkmadığını, halbuki ilim talebesinin el-Câmiu's-sağîr ile Sahîh-i Buhârî̀den daha fazla meşgul olduğunu söylüyor. ${ }^{91}$

90 Babam Fahreddin Hazret'in 1879 tarihinde Hac seferinden getirdiği yazma Mesâbîhu's-sunne sonunda nüshanın H. 774'te Eyyub b. Yakub ÇáÇĖßÑãí tarafından ĖÑæÓÇ Bursa (?) beldesinde istinsah edildiği kaydedilmektedir.

91 Kutub-i Sitte ve Müellifleri, s. 111-115. 


\section{HADIS ŞERHÇILIĞi}

Hz. Peygamber'den gelen hadis ve sünnetlerin dindeki yeri ve önemini çok iyi kavramış olan Rızaeddin b. Fahreddin, İslam'ın bu ikinci kaynağının doğru bir şekilde anlaşılması ve yorumlanması gerektiğinin farkındaydı.

Ona göre hadisleri anlamada yardımcı olan hususlar şunlardır: Arapçayı ve nasıl kullanıldığını iyi bilmek, Arap şiirini ve mesellerini ezberlemek, sahabe, tabiûn ve bunlar arasında din ilmi ile iştiğal eden zatların biyografilerini bilmek, onların asırları, muhitleri ile aşina olmak. ${ }^{92}$

Her ne kadar elinde birçok hadis şerhi bulunmakta ise de, o hadislerin kendi döneminde, kendi ihtiyaçları doğrultusunda yeniden şerhedilmesini, kısaca güncelleştirilmesini arzu etmekteydi. Yaşadığı ortamın da etkisiyle birçok problemlerle karşılaşan ve bunlara çözüm yolları arayan ve bu sebeple birçok dalda irili-ufaklı eserler telif eden Rızaeddin b. Fahreddin, iki ayrı hadis şerhine de imza atmıştır:

\section{A. Cevâmiu'l-kelim Şerhi}

Rızaeddin b. Fahreddin, eseri yazış sebebi olarak, daha önce hem Arapça okumaya başlayan talebeler için ders kitabı, hem de ahlakî açıdan yardımcı olması bakımından "Cevâmiu'l-kelim" isimli bir risale tertip ettiğini, ancak daha sonra bu hadislerin terceme ve şerhedilmesi gereğini, hem tecrübe ile hem de başkalarının bu yoldaki tenbihleriyle anladığını ve bunun üzerine fırsat bulup bu şerhi telif ettiğini kaydetmektedir. Alfabetik olarak tertip edilen eserde, harekeli ve rakaml olmak üzere toplam 317 hadis bulunmaktadır. İlk defa Orenburg-1916'da basılan kitap, en son 1996'da Kazan'da ofset olarak yeniden neşredilmiş olup, 525 sayfadır.

Girişte kadın-erkek her müslümanın ilk emri "oku!" olan dinini bilmesi, farz olan ilmi tahsil etmesi ve Hz. Peygamber'i tanıması gereğinden söz eden Rizaeddin b. Fahreddin, hadis ve sünnetlerin naklinden bahsettikten sonra Hz. Peygamber'den sahih senedlerle nakledilen hadislerin ümet için "düsturu'l-amel" (davranış yasası) olması gereken "kaideler", dünya ve ahiret saadetine eriştiren yollar olduğunu belirtir. ${ }^{93}$

Müellif, eseri telif ederken muteber şerhlerden istifade ettiğini, çoğu ahlakî ve ictimaî konularda olan hadisleri terceme ederken harfî terceme ile değil, mazmununu alarak serbest çeviri kullandığını söyler. ${ }^{94}$

92 A.g.e., s. 47.

93 Bkz: Cevâmiu'l-kelim Şerhi, s. 5, 90, 434-435.

94 A.g.e., s. 5-6. 
Mesela bir hadiste ${ }^{95}$ geçen "köleleriniz" ifadesini güncelleştirerek "hadimleriniz" şeklinde çevirmiştir. ${ }^{96}$

Bu kitabın muallimler için ders kitabı, okuyup yazanlar için de bir müracaat kitabı olması halinde kendisinin bahtiyar olacağını belirtir. İçinde bulunduğu hayat ve ahvale dair uygun olarak seçtiği hadisleri, İslam hafızlarının fikirleri doğrultusunda açıklamaya gayret gösterdiğini, bunun ötesinde mazur olduğunu belirttikten sonra, Hak Teala'nın bu eseri "el-bâkıyâtu'ssâlihât" (kalıcı salih ameller) cümlesinden eylemesini ve vefat ettikten sonra da okuyucuların kendisi için dua etmelerini istemektedir. ${ }^{97}$

Müellif eserin hatimesinde, ravilerin kendi kitapları olmadığı için kitapta zikrettiği bazı hadisleri "et-Terğ̂̉b ve't-terhîb", "Mesâbîhu's-sunne" ile "el-Câmiu's-sağîr" adlı eserlerden naklettiğini, ancak bu tür hadislerin az olduğunu, hadislerin çoğunun Kutub-i Sitte ile Ahmed b. Hanbel'in Musned'inden seçildiğini ve her hadis için bir-iki kaynak gösterildiğini belirtmektedir. ${ }^{98}$ Seçtiği hadislerden bazıları hakkında hadis imamlarının (tenkid içeren) sözleri bulunduğunu bilse de, onların uydurma olduklarını iddia ettikleri de bilinmemektedir. Sözkonusu tenkidlerin sadece raviler cihetinden olması sebebiyle onları nakletmekte bir beis görmemiştir. Kaldı ki bu kabil hadislerin sayısı da dört-beşi geçmemektedir. ${ }^{99}$

Kur'an ve sünnete sarılmanın anlamı üzerinde duran müellif, mevcut Kur'an ve Sünnet anlayışını eleştirmektedir. Sünnete sarılma, mezhebe muhalif olan hadisleri, sırf bu yüzden reddedip, anlamına ve hükmüne itibar etmeme, lafızlarını sırf teberrük için okuma demek değildir. Hadis kitapları, onlarla amel için değil, çeşitli umumi felaketlerden koruması için okunmakta, sahih hadislerle mevzu hadisler birbirinden ayırdedilmemektedir. Kur'an ve Sünnete sarılma, onları her bir mukallidin ve müctehidin sözünden üstün tutma, imkan nisbetinde her biri ile amel etme demektir. Eğer bu mümkün değilse elinden geldiği kadarıyla tearuz kaidelerine göre birini tercih etmek veya hangisine gönlü yattıysa onunla amel etmek demektir. ${ }^{100}$

Ona göre, Kur'an ile hadise ehemmiyet verilmemesi sebebiyle İslam dünyası asılsız fetvalar ile doldu, "hîle-i şer'iyye" denilen şeylerle amel edilip

95 Buhari, İman 22, I. 13; Itk 15, III. 123; Muslim, Eyman 40, II. 1283; Tirmizî, Birr 29, no: 1945, IV. 334; Ebû Dâvûd, Edeb 133, no: 5157-8, V. 359-360; Ahmed, Musned, V. 161.

96 Cevâmiu'l-kelim Şerhi, s. 28.

97 A.g.e, s. 6.

98 Hatimede böyle demesine rağmen, kitapta şu numaradaki hadislerin kaynakları verilmemiştir: $39,47,58,60,70,87,105,108,115,119,121,125,134,140,143,145,151,152,154,155$, $159,160,161,165,166,172,173,177,178,179,180,181,184,186,193,206,211,216,130$, $236 \ldots$

99 Cevâmiu'l-kelim Şerhi, s. 544.

100 A.g.e, s. 184-185. 
duruldu. Oysa İslam dünyasının, Kur'an ve hadislere gerektiği gibi âşina olmaları, onlara uygun amel etmeleri, ayrıca peygamberlerinin sîreti, dört halifesinin siyasetleri, sahabenin muameleleri ile pek yakından tanışmaları gerekliydi. Bunlar, ümmetin hak yolda olup olmadığını net ve doğru bir şekilde gösteren ölçülerdir. ${ }^{101}$

Hadisleri kaynaklara nisbetteki titizliği dikkat çekmekte, zaman zaman bazı kitaplarda gördüğü çeşitli hatalara işaret etmektedir. "Beş şeyden önce beş şeyi ganimet bil!" hadisini ${ }^{102}$ Mişkat sahibinin Tirmizîye, başkalarının ise Nesaî'ye nispet etmelerinin yanlış olduğunu, söz konusu hadisin ne elCâmi'de, ne de el-Müctebâ'da yer aldığını belirtmektedir. ${ }^{103}$

Hz. Ali'nin bir Yahudi ile Kâdî Şurayh'ın huzurunda mahkemeleştiğine dair rivayetin tarih kitaplarında bulunduğunu, ancak kütüphanesindeki mevcut meşhur hadis kaynaklarında bulunmadığını belirterek, bunun sahihlik derecesini sormaktadır. ${ }^{104}$

Muslim'den naklettiği "ed-Dînu en-Nasîha"105 hadisinin, Buhari'de talik yolu ile rivayet edildiğini belirtmektedir. ${ }^{106}$

Hadisin merfu veya mevkuf olup olmadığı meselesine girmemekte ${ }^{107}$, aynı şekilde Hadisin meşhur bir söz olup olmadığı konusunda hassasiyeti gözükmemektedir. ${ }^{108}$ Buradan müelifin, seçmiş olduğu metnin içeriğini ve verdiği mesajı öncelediği anlaşılmaktadır.

\section{Bazı ilginç ve güzel yorumları}

İnsanları yüzlerine karşı öven kimselerin yüzlerine toprak atılmasını emreden hadisteki ${ }^{109}$ "yüze toprak atma" tabirinin, övülen kimseden bir şeyler elde etmek isteyen kişiye bir şey vermemek, ya da az vererek ağızlarını kapatmaktan kinaye olduğunu söyler. Sahabeden Mikdad b. el-Esved'in, bu hadisin zahiri ile amel ettiğine işaret eden müellif, hadiste geçen "meddâh" ifadesinin 'çok medhedici' anlamına geldiğini ve bununla ister şiirlerle, isterse nesirle olsun asılsız ve batıl sözlerle övgüler düzenlerin kastedildiğini belirtir. Aksi takdirde, mübalağa ve yalandan uzak olan ve doğru sıfatlarla yapılan övgülerin yasak olmadığına ve bu hadise muhalif düşmediğine dik-

101 A.g.e, s. 186.

102 Hakim, Mustedrek, IV. 306; Acluni, Keșfu'l-hafâ, I. 166-7, no: 436.

103 Cevâmiu'l-kelim Şerhi, s. 67/1.

104 Age, s. 346/1.

105 Muslim, İman 95, I. 74; Buhari, İman 42, I. 20'de bab başlığı olarak.

106 A.g.e, s. $217 / 3$.

107 A.g.e, s. 25-26.

108 A.g.e, s. 55.

109 Muslim, Zuhd, 69, III. 2297; Ebu Davud, Edeb 10, no: 4804, V. 153. 
kat çekmektedir. Nitekim, Hz. Abbas ve Hassan b. Sâbit gibi bazı sahabiler, Hz. Peygamber'i överek şiir söyledikleri halde, Rasulullah (s)'ın onların yüzlerine karşı toprak saçtığı rivayet edilmemiştir. Hatta bizzat Hz. Peygamber de "Ben klyamette ademoğlunun efendisiyim"110 buyurmuştur. Yusuf peygamber de "Beni hazinelerin başına görevlendir, zira ben hem iyi koruyan, hem de bu işleri çok iyi bilenim"111 diyerek Mısır hükümdarına kendisini tanıtmıştı. ${ }^{112}$

İki hanımı arasında adaleti sağlayamayan kişinin akıbetinden söz eden bir hadisin şerhinde, çok ve tek eşlilik konusunu ele almaktadır. Müslümanlar için dört hanıma kadar evlenmenin mutlak olmadığını, bunun hastalık, çocuksuzluk vb. zaruret durumlarında verilen bir ruhsat olduğunu, edep ve ahlak noktasından bazı kişiler içinse menedildiğini belirtir. Bu ve benzeri mazeretler olmadığı sürece hatun üzerine hatun almaktan sakınılması gerektiğini hatırlatmaktadır. ${ }^{113}$

Bir hanımla dört şeyden dolayı evlenileceğini bildiren hadisteki ${ }^{114}$ "Sen dindar olanı seç!" ibaresini izah ederken, kişinin evleneceği hanımı az birşey görmekle onun dinli mi, dinsiz mi olduğunu ayırdetmenin mümkün olamayacağını, bu nedenle dindar olup olmadığının iyice öğrenilmesi gerektiğini tavsiye etmektedir. ${ }^{115}$

"Siz dünyanızın işlerini benden daha iyi bilirisiniz!"116 hadisinin izahında bariz bir şekilde "din-dünya ayırımı" yapan müellif, müslümanların dini işlerinde kanun-i esaslarının Kur'an-1 Kerim ve Rasulullah'ın Sünneti olduğunu ve onlara başvurmaları gerektiğini; dünyevi ilimler ve işler hakkında ise kendilerinin teftiş ve tecrübeleri ve akıllarını kullanmaları gerektiğini söyler ${ }^{117}$. Din ilmi ile dünya ilmini; örf ve adet ile din işlerini ayırmak gerekir, zira biri vahy ve peygamberlerden öğrenilmekte, diğeri ise ademoğlunun tecrübelerine dayanmaktadır. Müellife göre bu hadis, müslümanlarca bir düstur olarak görülmelidir. Din ile ilgili olmayan dünyevi işler ve ilimlerde kendi tecrübeleri ve ictihadları ile çalışıp, diğer milletlerden geri kalmamaları gerekmekteydi. Lakin müslümanlar bu kaideyi kendilerine düstur etmediler, din işi ile dünya işini ayırdetmeyip, herşeyi şeriata tatbik etmeye

110 Buhari, Enbiya 3, IV. 105; Tefsir İsrâ 17/5, V. 225; Muslim, İman 327-8, I. 184-7; Ahmed, Musned, I. 281, 295, II. 435, 540, III. 2, 144, V. 388.

111 12. Yusuf 55.

112 Cevâmiu'l-kelim Şerhi, s. 26-27.

113 A.g.e., s. 44.

114 Buhari, Nikah 15, VI. 123; Muslim, Rada' 53, II. 1086; Ahmed, Musned, II. 428.

115 Cevâmiu'l-kelim Şerhi, s. 192.

116 Muslim, Fedail 141, II. 1836; Ahmed, Musned, I. 162, III. 152.

117 Cevâmiu'l-kelim Şerhi, s. 87-88. 
kalkıştılar. Son zamanlarda müslümanların yedikleri darbelerin en büyügüü ve en acısı, dünyevi işlerin din adına engellenmesi ve bu hususta da "İslam dini ile medeniyet birbiriyle bağdaşmıyor!" şeklinde ikinci bir batıl davaya dayandırılması olmuştur. Sultan Murad'ın İstanbul'da rasathane açmaya giriştiğinde, İstanbul alimleri, rasathanelerin açılmasına ve Felsefeye dair eserlerin okunmasına karşı çıtılar ve din adına fetva verdiler. Zira, İstanbul'da bütün dersler "Hidâye" ile "İnâye" okutmaktan ibaretti. Rasathanenin din ile ne alakası var!? Hangi Kur'an (ayeti) onu men etmektedir!? Sultan Mahmud'un zamana uygun olarak askere nizam vermesine de aynı gerekçeyle karşı çıkıldığını, ancak Sultan'ın dini iyi bildiği için buna kulak asmadığını hatırlatır. Aynı şekilde Buhara alimleri de çocukları Usûl-i cedid ile "elifbâ" okutmaktan menettiler ve din adına mekteplerini kapattılar. ${ }^{118}$

"Allah ümmetimi dalalet üzere birleştirmez. Allah'ın eli, cemaatin üzerindedir"119 hadisinde geçen "yedullah" yani "Allah'ın eli" ifadesinin insan eli gibi bir organ olarak anlaşılmamasını, bundan muradın, Allah Teala'ya uygun bir sıfat olduğunu belirtir. ${ }^{120}$ Aynı hadisteki "cemaat" ifadesi de muteber şarihlere göre, Kur'an ve Sünnet'e bağlı olup Rasulullah'ın yolunu izleyenlerdir. Müellif, buradaki dini cemaati, Hicaz ve Buhara alimlerinin Eş'arî ve Mâturîdî̀ye tabi olanlar şeklinde tahsis etmelerini, itimadsız adamların, delilsiz ve hayali sözleri olarak nitelendirmektedir. ${ }^{121}$

"Allah bu ümmete, her yüz yıl başında dini yenileyecek kimseler gönderir"122 hadisini açıklarken, Rasulullah'ın zamanında hadiselerin tesbiti için genel bir tarih bulunmadığını, sözkonusu yüzyılı, Hz. Peygamber'in doğumu, hicreti veya vefatından itibaren yüzyll şeklindeki belli tarihlere hamletmenin uygunsuz olduğunu, bundan maksadın, "her asırda ve her zamanda" demek olduğunu kaydeder. Hadisteki "men" ifadesi, birçok müceddidin olabileceğini ortaya koymaktadır. Ancak, bid'at ve hurafeye destek verenler ile mukallidlerin müceddit olamayacağında şüphe yoktur. Aksine, sözkonusu mücedditler, Kur'an ve Sünnet ilimlerinde mütehassis olan ve ilimleriyle amel eden kimseler olmalıdır. Bunların telif ve eserleri az veya çok olsun, şöhretleri kendi asırlarında bilinsin ya da bilinmesin farketmez. Yine Kur'an ve hadis ilimleriyle meşgul oldukları halde, dirayetsiz ve tahkiksiz, sadece rivayet ve nakil ile iştigal edenlerin de müceddit olabilme ihtimali yoktur. Hadis-i şerif, 'ilim' ve 'tasavvuf mücedditlerini değil, yalnız 'din' mücedditlerini zikretmektedir.

118 Cevâmiu'l-kelim Şerhi, s. 88-89.

119 Hakim, Mustedrek, I. 115.

120 Cevâmiu'l-kelim Şerhi, s. 109.

121 Cevâmiu'l-kelim Şerhi, s. 110.

122 Ebu Davud, Melahim 1, no: 4291, IV. 481; Hakim, a.g.e, IV. 522. 
Akidemizin yalnız kat'î delillere dayanması sebebiyle, âhir zamanda gökten İsa Peygamber'in ineceği, yerden de Mehdî’nin çıkacağını itikad kılmasak da, İslam dünyasında sonradan ortaya çıkan her türlü mezhep ve meşrepleri bitirip, bütün müslümanları Kur’an ve sünnet ilimleri (alimleri) arasında çıkacak din mücedditlerinin zuhur edeceğine imanımız tam ve ümidimiz büyüktür. "Hayırlı ümmet" ile şereflendirdiği bu necip milleti, şeriatlerin en kamiline ve esaslı kanununa tabi olan bu cemaati Allah Teâlâ böyle darmadağınık bir halde bırakmaz, vehm ve hurafeler karanlıklarında kalmalarına razı olmaz. ${ }^{123}$

Hanımların yapacakları yolculukları hakkında Kur'an'da herhangi bir hükmün olmadığını belirten müellif, "Kadın, ancak yanında mahremi ile yolculuk yapabilir" şeklindeki Buhârî ve Muslim hadisini ${ }^{124}$ alimlerin umuma hamletmeyip, zaruret hallerini istisna ettiklerini belirtir. Gücü yetenlerin haccetmesini isteyen ayetin ${ }^{125}$ erkekler kadar hanımlar için de geçerli olduğunu söyleyenlerin bulunduğunu hatırlattıktan sonra, bu konuda başka bir delil daha zikreder. Buhârî’nin Adiyy b. Hâtim'den rivayet ettiğine göre "Hîre'den çıkıp Allah'dan başka kimseden korkmadan Kâbe'ye kadar gelip onu tavaf edecek hanımı göreceksiniz!" 26 hadisinden hanımların, erleri ve mahremleri olmaksızın da yolculuk yapabilecekleri anlaşılmaktadır. Çünkü Rasulullah'ın bu sözü, İslam'ın güçlenip, güvenliğin gerçekleşeceğini beyan etmektedir. Mahremleri olmaksızın hanımların yolculuk yapmalarının yasaklanması, hanımların tahkir edilmeleri hakkında korkulması illetine dayanmaktaydı. İlletin yok olmasıyla, yasak hükmü de kalkar. Bu delile göre, güvenliğin tam olması şartıyla hanımların mutlak olarak yolculuk yapmaları sahih olur. Maîşet ve dünya hayatının icbar ettiği üzere, bu zamandaki çok müslümanlar için İbn Hazm'ın "Eri ve mahremi bulunmaksızın, hanımın, hac ve başka yolculuklar yapabileceği" şeklindeki sözüne uymaya mecburiyet vardır. ${ }^{127}$

"Hanımlara yazı yazmayı öğretmeyin, onları yola bakan odalarda oturtmayın!" şeklindeki hadis ${ }^{128}$, mütehassıs alimlere göre uydurmadır. Uydur-

123 Cevâmiu'l-kelim Şerhi, s. 117-119.

124 Buhari, Taksir 4, II. 35-6; Muslim, Hacc 413-424, I. 975-978.

125 Al-i Imran, 97.

126 Buhârî, IV. 175-176.

127 Cevâmiu'l-kelim Şerhi, s. 167-168.

128 Hakim, Mustedrek, II. 396. Zehebî, Telhis'inde bunun uydurma olduğunu belirtmektedir. Bkz: İbnu'l-Cevzî, el-Mevdûât, II. 268-269'da Hakim'in böyle bir uydurma haberi nakletmiş olmasına şaşırmaktadır. Cahız'a (ö. 255/868) göre bu ifade, H. III. asrın başlarında halk arasında söylenen bir sözdür. Bkz: el-Beyan ve't-tebyîn, II. 180, Tahk. A. M. Harun, Beyrut, 1990. 
ma olmaması durumunda dahi, kendinden daha güvenilir hadislere muarız olduğundan onu delil olarak ileri sürmek mümkün olmazdı. Şeriatın maksadı, ümmetini ümmilikten çıkarıp onlara kitap ve hikmet öğretmek olunca, bundan hanımları ayırmak doğru değildir. Nitekim İmam Ebû Dâvud, Şifâ bint Abdullah'dan, "Hafsa'nın yanındayken Rasulullah (s.a.v) yanıma girdi ve 'Buna Karınca duasını öğrettiğin gibi, yazmayı da öğretsen ya!?' buyurdu" hadisini rivayet eder. ${ }^{129}$ Rasulullah'ın bu sözü, hanımların yazı bilmelerini istediğine delalet eder. ${ }^{130}$

"Sizden biri, ayakta su içmesin! Unutup içerse kussun!"131 hadisinin bilerek içen için de geçerli bir hüküm olduğunu belirten müellif, İbn Hazm'ın bu hadisin zahirinden hareketle, su, çay ve kahve vb. mübah nesneleri ayaktan içmenin haram olduğunu iddia ettiğini kaydeder. Cumhur ise, hadisi tenzihen (mekruhluk) ve evla bir ameli beyan babından olduğu görüşündedir. İmam Muhammed (eş-Şeybânî) Muvatta'da ${ }^{132}$, Hz. Aişe ve Sa'd b. Ebî Vakkâs'ın ayakta içmede bir beis görmediklerini, Hz. Ömer, Osman ve Ali'nin de ayakta iken içtiklerini, kendilerinin de ayakta içmeyi şeriata ayk1rı görmediklerini, Ebû Hanîfe ve ashabından fakihlerin de aynı görüşte olduklarını söyler.

Bu hususun cevazına dair İbn Abbas, Hz. Ali, İbn Ömer ve başkalarından gelen bazı rivayetleri ${ }^{133}$ naklettikten sonra, cumhurun, ayaktan yeme-içmenin şeriata göre doğru olduğunu, bunun günah olmadığını, ama sakınmanın daha iyi olduğunu söylediklerini zikreder. Buna göre her iki taraftaki hadisler de yerlerinde geçerli kalmaktadırlar. ${ }^{134}$

Rasulullah'ın ayakta iken (su vb.) içtiğini delil getirerek birçok kişinin Zemzem suyunu da ayakta içtiklerini, oysa şarihlerin belirttiğine göre burada Rasulullah'ın tavafı tamamladıktan sonra içtiğini, otururken ayağa kalkmadığını, ayaktayken ikram edilen Zemzem'i ayaktayken içtiğini hatırlatır. Hatta Hz. Peygamber'in Zemzem'i ayakta içtiğine dair İbn Abbas hadisini sahih görmeyen İkrime'nin yemin ederek Rasulullah'ın Zemzem'i deve üstünde otururken içtiğini haber verdiğini nakleder. ${ }^{135}$ Buna göre, otururken ayağa kalkıp içmek yerine, ayaktayken oturup içmek gerekir. ${ }^{136}$

129 Ebu Davud, Tib 18, no: 3887, IV. 215; Ahmed, Musned, VI. 372.

130 Cevâmiu'l-kelim Şerhi, s. 296-297.

131 Muslim, Eşribe 116, II. 1601; Abdurrazzak, el-Musannef, X. 427, no: 19588.

132 Malik, el-Muvatta (Şeybânî rivayeti), s. 314, no: 880-1.

133 Beyhaki, es-Sunen, VII. 282-283.

134 Cevâmiu'l-kelim Şerhi, s. 359-360.

135 Buhari, Hacc 76, II. 167; İbn Mace, Eşribe 21, no: 3422, II. 1132.

136 Cevâmiu'l-kelim Şerhi, s. 361. 
Bir kişinin hidayetine vesile olmakla ilgili hadisin ${ }^{137}$ şerhinde, talebe okutanların, ilim neşriyle uğraşanların, mektep ve medrese yararına mal harcayanların 'bizim vesilemizle çocuklar hidayet bulsalar' diye niyet etseler, elbette işbu hadisin müjdesine nail olacaklarını belirtir. ${ }^{138}$

"Küçüklerimize merhamet etmeyen, büyüklerimizin hakkını bilmeyenler bizden değildir"139 hadisini genişçe açıkladıktan sonra, "Herhalde işbu hadis-i şerif, (sadece) müslümanlığın değil, belki insanlığın da mizanıdır. Küçüklere hürmetsiz, büyüklere ihtiramsız olan kişiler, müslüman sıfatında görülmesi mümkün olmadığı gibi, insan suretinde görülmeleri de mümkün olmaz" der. ${ }^{140}$

"Bir kişi, bizim dinimiz cümlesine, dinimizden olmayan bir asıl ve kaideyi, ya da bir türlü itikad ve amelini ihdas k1lsa, o şey kendisine reddedilir"141 hadisi üzerinde genişçe duran müellif, gemi, demiryolu ve telgraf gibi icatların bid'at sayılamayacağını, asıl bid'atlerin Rasulullah rivayet edilmeyen akide ve çeşitli ibadetler nev'inden olduğunu belirttikten sonra, misal olarak ihdas edilip dine sonradan sokulan bazı amel ve ibadetleri zikreder:

1. Aşure: Allah'a yaklaşma kasdıyla, Şiiler Muharrem'in onuncu gününü "taziye"; kendilerine Sünnî ismini verenler de "bayram" kılma âdetini ihdas ettiler. Bu iki firkanın ihdas ettiği işbu amelleri, 'bid'at' ve de 'dalalet' hükmü verilen muhdes işlerdendir.

İki fırkanın amellerini tartışan müellif, Şiîler tarafından Aşûre taziyesi ihdas edilince, sırf onlara karşılık olsun diye muhaliflerin de Aşûre bayramı diye bir bayram çıkardıklarını, bu doğrultuda aslı faslı olmayan hadisler uydurduklarını belirtir. Aşûre gününde oruç tutmanın faziletli bir amel olduğu hakkında sahih hadis var ${ }^{142}$, ama bundan başka şeyler hakkındaki hadisler uydurma ve yalandır. Bu sahih hadislerden de maksad, vaaz kitaplarındaki ifrat derecesinde sevaplar vadedilen hadisler değil, belki güvenilir muhaddislerin rivayet ettikleri hadislerdir. Aynînin "Allah Teâlâ, Aşûre gününde on peygamberini on kerametle hürmetledi" diyerek o peygamberlerin isimlerini ve maceralarını birer birer sayması, Sahîh-i Buhârî gibi, muteber bir hadis kitabına yazılan şerhe böylesi düşük haberleri sıralaması pek teessüf edilecek bir haldir!"

137 Buhari, Cihad 102, 143, IV. 5, 20; Muslim, Fedailu's-Sahabe 34, II. 1872; Ahmed, Musned, V. 238, 333.

138 Cevâmiu'l-kelim Șerhi, s. 366.

139 Tirmizi, Birr 15, no: 1921, IV. 322; Ahmed, Musned, I. 257, II. 207.

140 Cevâmiu'l-kelim Şerhi, s. 387.

141 Buhari, Sulh 5, III. 167; Muslim, Akziye 17-8, II. 1343-4; Ebu Davud, Sunne 6, no: 4606, V. 12; Ahmed, Musned, VI. 270.

142 Buhari, Savm 69, II. 251; Muslim, Siyam 196, I. 819. 
2. Regâib ve Beraat Namazları: Haram olmayan vakitlerde nafile namaz kılmak iyi bir iștir. Lakin hususi şekillerde kılınan namazlar hakkında hususi delillerin olması gerekir. Bu nedenle, Recep ayında Regâib adında, Şaban ayında ise Beraat adında hususi nafile bir namaz kılmak bid'attir. Bu namazlar pek eski asırlardan beri devam edegelseler de, Ebû Tâlib Mekkî ve Ebû Hâmid Gazzâlî gibi hadis ve sünnet ilimlerinde meharetleri az olan sufiler tarafindan ihdas edildikleri mervidir.

3. Hevl Namazı: Bizim memlekette halk arasında farz gibi yürütülegelen bir adet de, muteber kimselerden biri öldügüünde Akşam namazından sonra müezzin halka ayak üzeri iki rekat namaz kıldırıp, "Kılınan bu namazın sevabını felan oğluna bağışladınız mı?" diye sorar, onlar da "bağışladık, bağışladık!" der ve ardından hep beraber dua ederler.

4. Mescidde İhtiyat-i Zuhr (Zuhr-i âhir) namazı kılınması,

5. Para vererek Kur'an'ı hatmetmek veya ettirmek,

6. Ruhlardan meded umarak, hacet istemek üzere kabirlere varmak,

7. Hanımları mescitlere gitmekten men etmek. ${ }^{143}$

Uydurma haberler sebebiyle, milletin fikirlerinin zehirlendiğini, memleketlerle devletlerin zayi olduğunu belirten Rizaeddin Fahreddin, hocaların tefsir adı altında uydurma hadisleri, Yahudi hikayelerini anlattıklarını ve böylece birçok vehm ve hurafelere neden olduklarını hatırlattıktan sonra şu anektodu anlatır:

"Bir mollanın minberde oturup, yerin öküz ve balık üstünde olduğunu söylediğini dinledikten sonra müslüman bir öğrencinin 'İslam Dini böyle ise ben bundan çıarım!” diyerek gittiğini işittim. Burada ayıp bu öğrencide değil, aksine yalan ile doğruyu ayırtedemeyen, bulunduğu yeri farkedemeden söz söyleyen molladadır..." 144

"Selamı yayınız!"'145 hadisini şerhederken, tanınan tanınmayan herkese selam verilmesini izah ettikten sonra, şu geniş yoruma yer verir: "Selamı yayınız!"ın anlamı, esenlik, güvenlik ve barış vesilelerini yaygınlaştırınız! şeklinde olması da mümkündür. ${ }^{146}$

Hadislerde ${ }^{147}$ geçen "sivâk" kelimesinin, dişleri yıkamak ve korumak anlamına geldiğini, tıp cihetinden zararlı olmadığı sürece gerek ağaç dalıy-

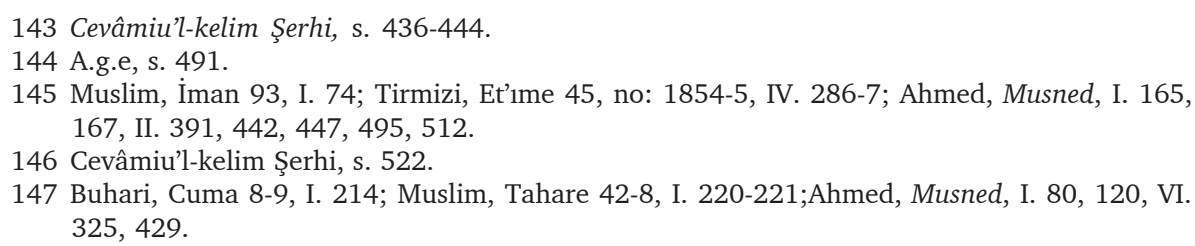


la, gerekse at kılından mamul fırça vb. başka bir şey ile dişlerin temizlenebileceğini belirterek misvak konusunda geniş bir yorum yapar ${ }^{148}$

Bir hadisi sahih diyerek nakledebilmek için, âdil ravilerin, iyi bir zabt ile Rasulullah'a ulaştırmaları şarttır. Bu zaman halkına göre bu işleri tespite güç yetmeyeceğinden, hadis sahasında muteber görülen asıllar ve malum müsnedlerden nakletmek yeterlidir. Çünkü bunlarda da bazı sahih olmayan hadisler var ise de, bugün artık onlar muteber oldular. (Fakat) Hadis tenkitçileri onları sahih hadislerden ayırıp koydular.

"Kim benim adıma kasten yalan söylerse..." hadisini ${ }^{149}$ şerhederken de şunları söyler: Herhalde Kur'an-1 Kerim'e veya akla aykırı olup da, bu muteber asıllarda görülen hadisleri sahih hadisler deyip hükmetmek de doğru değildir. Bu nedenle, gerek terğib-terhib kasdı ile gerek başka büyük bir maslahat ve kamuyararı mülahazası ile gerekse ahkam ve başka hususlarda olsun bu hadisin hükümüne göre Rasulullah Hazretlerine yalan ve uydurma hadisler isnad etmek haram iştir. Hatta sahihlikleri şüpheli olan hadisleri nakletmek bile doğru olmaz. ${ }^{150}$

Fakirlikten Allah'a sığınmayı emreden bir hadisin ${ }^{151}$ şerhinde müellif şunları açıklamaktadır:

Fakirliği zemmeden hadisler olduğu gibi, "Mü’minlerin fakirleri, Cennet'e, zenginlerden yarım gün=beşyüz yıl önce girecekler" gibi fakirliği medheden hadisler ${ }^{152}$ de var. Lakin bu medh ve zemler, kişilere, yer ve asırlara, zenginlik ve zorda kalmışlıklara göredir. Bunun için Rasulullah'ın hadisleri arasında muhalefet yoktur. Biri için fakirlik iyi olsa da, öbürü için o fakirliğin "küfür" derecesinde zararlı olması mümkündür. Ama genel olarak millet için mutlaka varlıklı olmak iyidir ve bunda herhangi bir tartışma olmasa gerek. ${ }^{153}$

\section{2. Şerhte ele aldığı muhtelif konular}

Rızaeddin b. Fahreddin'in şerhte ele aldığı şu farklı konular dikkat çekmektedir: Modern ilimler (s. 104), edebiyatın önemi (s. 109), Frenk ve Rusların bazı güzel âdetleri (s. 97), Hızır ve İlyas'ın hayatları (s. 132/1), şiir (s. 138144), vakıf müessesesi (s. 146 vd.), dinde aşırılık (s. 160 vd.), Şedd-i Rihal

\footnotetext{
148 Cevâmiu'l-kelim Şerhi, s. 221.

149 Buhari, Ilim 38, I. 35-6; Muslim, Mukaddime 2, I. 9-10; Ahmed, Musned, II. 47, 83, 123, 150.

150 Cevâmiu'l-kelim Şerhi, s. 505.

151 Ahmed, Musned, V. 36, 39, 42, 44;VI. 57, 207.

152 İbn Mace, Zuhd 6, no: 4122-4, II. 1380-1; Ahmed, Musned, II. 296, 343, 451, 513, 519, V. 366.

153 Cevâmiu'l-kelim Şerhi, s. 190.
} 
Hadisini ${ }^{154}$ ihtilaflarla şerhi (s. 329-332), Hanımların mescidlerden menedilmemesi (s. 334), sarhoş edici içecekelerin haram oluşu (s. 92-4), İstihare namazı (s. 131-2), hanımların hukuku, ailedeki önemi (s. 214-6), "millet" kavramı ve anlamı (s. 220-1).

Şerhte doktorların sözlerine (s. 92-3, 209), Yunan filozoflarına, Aristo'ya (s. 176-7, 184-6), M. Abduh'dan uzunca bir alıntiya (s. 218-220), bir müsteşrikten alıntıya (s. 284), yer verdiği gibi, Musa Carullah'a da atıflarda bulunmakta (s. 334, 346/3), yer yer ilginç anekdotlar zikretmekte (s. 1778), güzel ahlak umdeleri hakkındaki uzunca yaptığı şerhini ailesine hediyye etmektedir. (s. 123-9)

Bu şerhin dikkat çekici bir başka yönü de, müellifin zaman zaman çeşitli kesimlere yönelttiği sert eleştirileridir: Bazı şerhleri tenkidi (s. 64/1), sahtekar hoca ve şeyhleri tenkidi (s. 90, 131-132, 163-166, 204-8), Buhâra ulemasını tenkidi (s. 87-90), geleneğin tenkidi (s. 184-186), kabir-türbe ziyareti ve kabirlere tevessül meselesi (s. 224-8, 348-9) mezhepler, ictihad ve telfik meselesi (s. 162) gibi. Her ne kadar bu denli eleştiriler yöneltse de, "Bazıları kendilerine "dinsiz!" deseler de, biz onlara "dinli" deriz" (s. 192-3) diyerek kendisi bu hususta insafı elden birakmaz.

Nesep ilmini öğrenmeyi tavsiye eden bir rivayetin şerhinde ise, bu ilme dair eserler ve yazarlar hakkında verdiği geniş malumat, onun literatüre ne kadar vakıf olduğunun bariz bir göstergesidir. ${ }^{155}$

\section{3. Şerhte kullandığı kaynakları}

Rızaeddin b. Fahreddin, bu şerhi hazırlarken, bilhassa kendi dönemi ve şartları dikkate alındığında oldukça çok çeşitli kaynaklardan istifade etmiştir. Zaten onun bu şerhinin önemi de, şerh esnasında zikretsin, ya da zikretmesin, onun sahip olduğu zengin bir kütüphane ve farklı mezhep ve branşlardan birçok referans kullanmasından kaynaklanmaktadır. Elbette 1900'lerin başlarında henüz kaynakların birçoğu basılmış değildi veya henüz kendisi elde edebilmiş değildi. Nitekim Ebû Dâvûd et-Tayâlisînnin Musned'ini ancak Hasan Efendi Akçurin kütüphanesinde görebilmiş, ama onu referans olarak kullanamadan bu kitap basılmıştır. ${ }^{156}$

Kutub-i Sitte, Ahmed b. Hanbel'in Musned'inden başka dipnotlarda vermiş olduğu referansları şöyle tasnif edebiliriz:

154 Buhari, Mescidu Mekke 1, 6, II. 56, 58; Savm 67, II. 249-250; Muslim, Hacc 415, 511-2, I. 976, 1014-5; Ahmed, Musned, II. 234, 338, VI. 7, 398.

155 Cevâmiu'l-kelim Şerhi, s. 189.

156 A.g.e, s. 544. 
Temel Hadis kitapları ve şerhleri:

Muhammed eş-Şeybânî, Muvatta,

Tebrizî, Mişkât,

İbn Münzir, et-Terğ̊îb ve't-terhîb,

İbn Hacer, Fethu'l-bârî,

Aynî, Umdetu'l-kârî,

Kastalânî, İrşâdu's-sârî,

Şevkânî, Neylu'l-evtâr,

Sıddık Hasan Han, Fethu'l-allâm şerhu bulûği'l-merâm,

Nevevî, Muslim Şerhi,

Tefsir kitapları:

İbnu'l-Arabî, Ahkâmu'l-kur'ân,

Beyzâvî, Envâru't-tenzîl,

Taberî, Câmiu'l-beyân,

Zemahşerî, Keşşâf,

F1kıh ve usûl-i fikıh kitapları:

Şâfiî, el-Umm,

Ebû Yusuf, Kitabu'l-harâc,

Serahsî, Mebsût,

Musa Carullah, Kavâid-i fikhiyye,

İbnu'l-Kayyim, I'lâmu'l-muvakkıîn,

İbnu'l-Humâm, Fethu'l-kadîr,

İbn Teymiyye, Fetâvâ,

Ricâl kitapları:

Zehebî, Tezkiratu'l-huffâz,

İbnu'l-Esîr, Usdu'l-ğâbe,

İbn Hacer, İsâbe,

Mercânî, Mukaddimetu vefiyyeti'l-eslâf,

Dil, küiltuirr, ahlâk ve edebiyat ile ilgili kitaplar:

İbnu'l-Esîr, en-Nihâye fi ğarîbi'l-hadîs,

İbnu'l-Kayyim, Zâdu'l-maâd ve iğâsetu'l-lehevân,

İbn Teymiyye, Minhâcu's-sunne,

Gazzâlî, İhyâ,

İbn Kuteybe, Uyûnu'l-ahbâr,

Asım Efendi, Kâmus,

İsfehânî, Ağânî,

Fîruzâbâdî, Sifru's-saâde,

İbn Arabî, el-Futuhâtu'l-Mekkiyye,

El-Müberred, el-Kâmil, 
Seyyid Murtaza, Emâlî, Ebu'l-Alâ el-Maarrî, el-Ğufrân,

Câhız, el-Hâsidu ve'l-mahsûd,

Mahmesânî, Muhtasaru câmiu beyâni'l-ilm,

Cürcânî, Delâilu'l-i'câz,

Sühreverdî, Avârifu'l-meârif,

Meydânî, Mecmau'l-emsâl,

Şemseddin Sâmî, Kâmûsu'l-a’lâm,

Muhammed Abduh'un bir makalesi,

Ahmed Bey Ağa, İstanbul Mektuplart,

Şûrâ Dergisi...

A. el-Belâğu'l-mubîn ve Şerhi (1918-1924)

Rızaeddin b. Fahreddin'in, 1918 yılında Ufa'ya ikinci defa gittiğinde, Diniye Nezareti tarafından Örnek adıyla dini bir medrese açıldı ve orta 2. sınıf dersleri için bir hadis kitabına ihtiyaç görüldü. Bunun üzerine, bir hadis kitabı tertip etmeye niyet eden müellif, istihare de yaptıktan sonra Allah'dan yardım dileyerek bu işe başlar.

Eser hakkında İslam Mecellesi'nde bilgi veren Rızaeddin Fahreddin, o günkü şartları şöyle tasvir eder: "el-Belâğu'l-mubîn,memleketteki iç savaşların olduğu bir zamanda tertip edildi. Şehrin üstünde gülleler havada uçuşurken, halk gizlenmek için yeraltına çekilir ve tüm giysilerini giyerlerken ben aksine üstümü çıkarıp bu eseri tertibe giriştim. Hadis-i Şerif bereketiyle olsa gerek, yakınımıza dahi gülle düşmedi; üstümüzden geçip gidenlerinse bizimle işleri olmadi." ${ }^{157}$

18 Temmuz 1922'de Ufa'dan, Abdurrahman Umerî̀ye ${ }^{158}$ gönderdiği mektupta şunları söylemektedir:

"el-Belâğu'l-mubîn'i tamamlamaya çalışıyorum. Çok zaman ve gayret sarfettim. Faydalanacak kimse çıkar mı çıkmaz mı bilmiyorum. Ya da fayda alınacak manası görülür mü görülmez mi, buna da şu anda cevap veremiyorum. "İlim üstünde ölen kişi şehiddir"159 mealindeki hadise uymak için "Nasıl olsa öleceğiz, hiç olmazsa şu iş üstünde öleyim!" diye devam ettim; yemek bulunmayan zamanlarda da bu işin başında bulundum. Kitaplarımın

157 "El-Belâğu'l-mübîn, izah", İslam Mecellesi, S. 9-10, 1925, s. 331-334.

158 1867'de Astrahan'da doğan ve 1933'te vefat eden bu meşhur alimin hayatı ve mücadelesi hakkında geniş bilgi için bkz: Rahimov Süleyman, Abdurrahman Ömerî, Kazan, 2003, Ruhiyat neşriyat1, 384s. Eser,Tatarca olup, Latin harfleriyle yazılmış, sonuna Rusça, Türkçe ve İngilizce özet konulmustur.

159 Bu lafızda herhangi bir hadis bulamadım. 
bir kısmının olsun dağılması işimi zorlaştırdı. İğne ile kuyu kazdım desem yeridir." 160

Kitabın ilk yarısını (bir kış dersliği) fikıh konularına göre, ikinci yarısını (2. sınıf) ise ahlak bahislerine göre tertip eder. Rasulullah'dan sadır olan sözleri topladığından bu eserine "el-Belâğu'l-Mübîn" adını verir. İslam dünyasında ortadan kalkmış olan Itâk, Mukâteb ve Mudebber yani kölelik ile ilgili hadislere yer vermez.

Hadisleri öncelikle ve doğrudan Kutub-i Sitte'den, nadiren de Muvatta ve Ahmed b. Hanbel'in Musned'inden alır. Elindeki mevcut şerhlerle, cerh ve tadil kitaplarının yardımıyla Muvatta, Ahmed b. Hanbel'in Musned'i ve İbn Mâce'nin Sunen'inden alınan hadislerin ravilerini bir nebze tedkik eder.

Asıl risaleyi tamamlamayı büyük bahtiyarlık ve başarı olarak görür ve bilahare Allah Teâlâ'nın kendisine şerhini de yazmayı nasip etmesini hayal eder. Bir süre bu eserdeki hadislerin şerhi konusunda Tebrizi'nin Mişkâtu'lmesâbîh'indeki hadisler için, onun üzerine Aliyyu'l-Kârînin "Mirkâtu'l-mefâtîh" adlı şerhinden yararlanılmasını önerir. Fakat daha sonra Allah Teala'nın rahmeti sayesinde kendisi bu eserine bir şerh yazmaya muvaffak olmuş ve öğrencilerin başka şerhlere bakmasına lüzum kalmamıştır.

Rızaeddin Fahreddin, hadislerin Mişkâtu'l-mesâbîh, et-Terğ̂̀b ve't-terhîb, el-Câmiu's-sağı̂̀r gibi çeşitli kitaplardan alındığı halde, "Bu hadisi Tirmizî rivayet etmiştir" denilmesini doğru bulmaz ve bunun en azından bir tür tedlis olduğunu söyler. Ona göre hadisler doğrudan doğruya bizzat o kaynakların kendisinden alınmalıdır.

Daha sonra bu kıymetli eseri tertip ederken kullandığı hadis kaynakları olan Buhari, Muslim, Ebu Davud, Nesai, Tirmizi, İbn Mace, Muvatta ve Ahmed b. Hanbel'in Musned'in hangi baskılarını kullandığını sayar. Kusurları ve hataları için Allah'dan af ve merhamet dileyerek eserinin tanıtımını tamamlar. ${ }^{161}$

Yazılması, 4-5 yıl devam eden 879 sayfalık bu değerli eser, halen el yazması olarak Diniye Nezareti Kütüphanesi'nde neşredilmeyi beklemektedir. ${ }^{162}$

Rızaeddin Fahreddin, daha sonra bu değerli eserinden bazı hadisleri de aynı derginin muhtelif sayılarında yayınlamıştır:

a. "Mü'min, cennete varıncaya kadar ilim tahsil etmeye doymaz"163 hadisinin şerhi, ${ }^{164}$

160 Ömer Hakan Özalp, a.g.e, s. 127-128.

161 "El-Belâğu'l-mübîn, izah", İslam Mecellesi, S. 9-10, 1925, s. 334-336.

162 Ayrıca bir nüshasının da Fenler Akademisi'nin Ural Şubesi, Başkırt Fenni Merkezi Arşivinde olduğu belirtilmektedir. Bkz: Özalp, a.g.e, s. 73, 127-128, 245-249, 314-317.

163 Tirmizi, ìlim 19, no: 2686, V. 50-1.

164 İslam Mecellesi, S. 3, 15 Aralık 1924, s. 92-95. Müminin, öleceği güne kadar ilim yolundan 
b. "Mü'minlerin imanca en kâmilleri, ahlakça güzel olanlarıdır; hayırlılarınız da kadınlarına hayırlı olanlarınızdır"165 hadisinin șerhi. ${ }^{166}$

c. "Allah, özürsüz yere üç cumayı kılmayanların kalbini mühürler!"167 hadisinin şerhi.

d. Cuma Namazı ile ilgili bir alınt1 ${ }^{168}$

e. "Kim, dinimizden olmayan bir asıl veya kaideyi, ya da itikad ve ameli din adı vererek dinimize sokarsa, o şey kendisine reddolunur"169 hadisinin şerhi $^{170}$,

Cevâmiu'l-kelim Şerhi ile el-Belâğu'l-mubîn şerhi arasında bir mukayese yapılacak olursa, sonki eserin, daha nitelikli olduğu anlaşılır. Mesela Cevâmiu'l-kelim Şerhi'nde bid'at ihdas etme hakkında yaptığ 1 yorumlarda, ihdas edilen çeşitli ibadetler üzerinde dururken, aynı hadisi el-Belâğu'l-mubîn'de tam bir usulcü gibi yorumlamakta ve meselenin felsefesini yapmaktadır. Mukayese imkanı vermesi bakımından bu kısmı nakletmekte fayda mülahaza ediyoruz:

"Herhangi bir akidenin veya amelin İslam dininden olduğunu iddia eden kişinin, bu iddiasını delillendirirken, Rasulullah'ın her bir amelini (fiilini)

yürüyeceğinin kastedildiğini ve bu hadisin, dinleri ve dünyaları için gerekli ilimlerle ilgilenenlerin sonunda birgün cennete gireceklerini bildirdiğini söylemektedir. Ardından tahsil noktasından ilmin nevileri üzerinde durmaktadır.

165 Tirmizi, Rada' 11, no: 1162, III. 466; Ebu Davud, Sunne 16, no: 4682, V. 60 (ilk kısmi); Ahmed, Musned, II. 250, 472, 527, V. 89, 99, VI. 47, 99.

166 İslam Mecellesi, S.9, 1927, s. 825-829. El-Belâğu'l-mübîn'den kısaltılarak alınmıştır ve önce insanların fitrî ve kesbî karekterlerinden, sonra Cahiliyye'de, Yahudilikte, Hristiyanlıkta ve Budizm'de kadına herhangi bir hakkın verilmediğinden, ona hor-hakir bakıldığından, oysa İslam'ın ona pekçok hakları verdiğinden bahsetmekte ve sonunda kadın hakları ile ilgili Bakara 2/228, Nisa 4/7, 19, 35, Rum 30/21 olmak üzere bes ayet zikretmektedir. Ayn hadisi, Câmiu'l-kelim Şerhi, S. 79-80'de de şerhetmiş, burada ise kısaca eşlerin birbirlerine karș sorumluluklarından bahsetmiștir.

167 Malik, Muvatta, Cuma 20, s. 111; Tirmizi, Salat 359, no: 500, II. 373; Nesai, Cuma 2, III. 88; Ahmed, Musned, V. 7. Rıza Fahreddin bu hadisin şerhinde, ilgili cezanın, cumayı hafif görerek terkedenler için sözkonusu olduğunu belirttikten sonra, Hz. Peygamber'in Cuma namazı uygulamasını uzunca anlatır. Ardından konu ile ilgili üç hadis daha naklederek açıklamasını tamamlar. İslam Mecellesi, S. 7-8, 1925, s. 260-262. Aynı hadisi, Câmiu'l-kelim Şerhi, s. 458459'da da şerhetmiş, orada da benzer açıklamalarla birlikte Cuma namazının sosyal yönüne ve farz kılınıs tarihine işaret etmiștir.

168 İslam Mecellesi, S. 11-12, 1925, s. 422-428. Müellif burada Cuma namazının farz kılınışından, Ebu Hanife'ye göre Cuma namazının şartlarından, Cuma vaazlarının öneminden ve nasıl olması gerektiğinden söz etmektedir. Bu alıntının, ilgili eserin fikıh kısmından alındığı anlaşılmaktadır. Dolayısıyla her ne kadar başlıkta "Hadis-i Șerif Dersi" denilmişse de, konu Cuma namazının fikhı ile ilgilidir.

169 Bkz: 25. dipnot.

170 İslam Mecellesi, S. 7-8, 1925, s. 257-262. Bu kısım Ömer Hakan Özalp tarafından, Rızaeddin Bin Fahreddin, s. 314-317'de yayınlanmıştır. 
veya sözünü vacip olan bir din gibi görmesi (doğru) olmaz. O'nun âdet yolu ile yaptığı işler vardır, sadece kendisine has olan fiilleri ya da, tabiî olan hususlar vardır. O zamanın örfüne binaen söyledikleri sözleri vardır. Belki, bir fiilin veya sözün 'din'(den) olması için, o fiilin Rasulullah Hazretleri tarafından 'din' adı ile ümmete tebliğ edilmesi şarttır. Birşeyin 'din' adı ile tebliğ edilmesi ise şu yollarla olur:

Kur'an veya sünnetten zahir (açık) veya hafî (kapalı) olan bir sened (dayanak/delil) getirmesi lazım:

1. Rasûlüllah onu açık bir şekilde 'din' veya 'ibadet' adıyla talim eder,

2. Onu yapmayanlar veya tutmayanlar hakkında tehdit ve korkutucu ibareler kullanır,

3. Yalnızca müstehab derecesinde olsa da, sevab vadeder,

4. Mendub olması durumunda, onun hakkında emir ya da emir manası çağrıştıran bir haber gelir.

Sözün kısacası şudur: Kulların sözleri ve işlerinin tamamı, ibadet ve adet olarak ikiye ayrılır. Dinleri için faydalı olan hususlar ibadet, dünyaları için faydalı veya zararlı olan, ya da dinleri tarafindan menedilen hususlar ise âdettir.

Birşeyin ibadet olması için, Şârî' (Rasulullah Hazretleri) tarafından bir türlü emir veya emir manasına gelen bir haber gelmesi, ya da Şâri'nin ibadet şeklinde kendi fiili bulunması gerekir. Yoksa, kendi aklı ile ibadet tertip etmeye, başka bir hususa kıyas ederek bir işi ibadet saymaya ümmetten hiçkimsenin hakkı yoktur.

Ĕger şeriat tarafından herhangi bir mani yoksa, âdeti yapıp yapmamakta serbesttir. Kulu bu işten menetmek ya da -belli bir vakitte umumi bir maslahat icap etmese-, o işi emretmek mümkün değildir. Bunun için, ibadet şeklinde görülen işler hakkında kulun vazifesi, o noktada durup, o hususta emir bulunup bulunmadığını araştırmaktır. Eğer o hususta emir bulunduğunu öğrenirse onu yapar, emir bulunduğu malum değilse onu yapmaz. Kula düşen vazife, sırf ibadete benzediği için, onu ibadet sayıp, onu ibadet adı ile yapmamaktır.

Bir kişi, şer'î bir delil olup olmadığını araştırmadan, sadece ibadet şeklinde görüldügüüne bakarak bir işi ibadet adıyla yapsa, "Yoksa onların, Allah'ın izin vermediği şeyi kendileri için dinden bir şeriat koyan ortakları mı var?!" (Şûrâ 42/21) ayetinin tehdidi altına girmekten emin olamaz...

"Bizim yolumuzda olmayan bir husus, ilave edilecek olsa bu merduddur" şeklindeki bu hadisten, kendi aklı ve ölçüsü ile dini bir amel tertip etmenin imkansızlığının açıkça anlaşılması gerek. İşbu sözlerden, şeriat ıstılahındaki 'bid'at'ın hangi hususlar olduğu kendiliğinden anlaşılmaktadır. Dünyevi işlerde, âdetlerde olması söz konusu değildir. Bid'atın, sadece dini işlerde 
bulunması mümkündür. Ama lügat açısından, her hususta bid'at bulunduğundan, o şeyler mezmum ve merdud değildir.

Lügat açısından bid'at, "misli/örneği geçmemiş yeni bir iş" demektir. Allah Teala'nın "Bedîu's-Semâvâti ve'l-Ard" "Gökleri ve yerleri benzersiz yaratan" (En'am 6/101) şeklindeki sözü de bu anlamda olsa gerek. Bid'atin şerîat katındaki manası ise "Kitab ve sünnette bulunmayan, Rasûlüllah'ın sahabileri asrında amel edilmeyen herhangi bir itikad ve ameli, din adı ile ihdas etmek"tir. Buna göre, Rasûlüllah (s.a.v.)'in bizzat yaptıkları ve yapılmasını emrettikleri veya görüp bilmelerine rağmen menetmedikleri ya da sahabiler zamanında karşı çıkılmaksızın yapılan ve rıza gösterilen ibadetler, itikadlar "sünnet, ibadet ve meşru bir iş" olup, bunların dışında kalan herşey bid'at ve dolayısıyla mezmum ve merduttur.

İşbu mukaddimelerden çıkan netice şudur:

Şeriat katında maruf olan bid'atin, hasenesinin olması ihtimali yoktur. Bilakis, bid'at olan hususların hepsi seyyie (kötü), hepsi merdud, hepsi mezmum ve dalalettir.

Bu hadis-i şerif, İslam dininde çok büyük ve küllî asıllardan biri sayılmakta ve onun altına pekçok hüküm girmektedir. Hasıll, eğer bir kişi, Kur'an ve sünnet tarafından beyan edilmeyen ve anlatılmayan bizzat sahabilerden nakledilmeyen bir hususu din adı ile yayacak olsa, o şey merduttur ve ona yol vermeyin, seyirci de kalmayın demek olur...

Birşeyin 'din' ismi ile Rasûlüllah (s.a.v.)'den ve hürmetli sahabilerinden nakledildiğini isbat etmenin yolu, Kutub-i Sitte'den, Muvatta ve Ahmed b. Hanbel'in Musned'inden, Tahâvî, Beyhakî ve bunların tabakalarından olan meşhur muhaddislerin eserlerinden nakletmek, cerh ve ta'n alimleri tarafından cerh edilmemiş olmaktır. Bu da bugünkü alimler için güç yetirelemeyecek şeylerden değildir; çünkü, muhaddislerin eserleri, hatta şerhleri her gün basılmakta; mevzûât, cerh ve tadil ilimlerine ait kitaplar da dünyanın her kıtasına yayılmaktadır..."171

Çok zor şartlarda yazılan bu kıymetli eserin, bir an evvel neşredilmesi gerekmektedir. Sadece neşredilen bu birkaç hadis şerhi dahi, eserin ne denli yararlı bir çalışma olduğunu ortaya koymaktadır.

\section{Sonuç ve Değerlendirme}

Tataristan'da yetişen ve imamlık, müderrislik, kadılık ve müftülük gibi en önemli din hizmetlerinin yanısıra, dergicilik ve gazetecilik de yapan Rızaed- 
din Fahreddin, XX. yüzyll Tatar ilim tarihinin abide şahsiyetlerinden biridir. Hayatının okuma-yazma, ilim ve araştırma ile geçen her bir günü, aynı zamanda müslümanların haklarını savunma, onlar adına dini ve siyasi arenada mücadele ile geçmiştir. O, hayatının en verimli ve de en zor zamanlarını geçirdiği Orenburg ve Ufa'da, müslümanca duruşundan, ilim adamının izzetine yaraşır tavrından ödün vermeden mücadelesini başarıyla gerçekleştirmiştir.

Eleştirel bir düşünce yapısına sahip olan Rızaeddin Fahreddin'in, Ufa Diniyye Nezareti Arşivi'ndeki binlerce el yazması ve matbu eseri kullanması, ilmi birikimini daha da zenginleştirmiş ve akranları arasında temayüz etmesini sağlamıştır. Sözkonusu arşivdeki birçok ilim dalına ait kaynaklar, ona kendisini çok yönlü yetiştirme fırsatını bahşetmiştir. Bu sayede o, akranlarının adını dahi duymadığı yüzlerce kaynağı kullanmak suretiyle, daha geniş düşünme ve taassuba kapılmadan meselelere yaklaşabilme yetisini geliştirmiştir. 1900'lerin başlarındaki imkanlarla da olsa, Kazan, İstanbul ve Kahire gibi ilim merkezlerindeki ilim ve fikir adamlarıyla yazışmak ve onların yazdıklarını takip etmek suretiyle ufkunu daha da genişletmiştir.

Rizaeddin Fahreddin, tarihten edebiyata, eğitimden ahlaka, biyografiden kültür ve sanata, felsefeden sosyolojiye ve bütün İslami ilimlere varıncaya kadar hemen her branşta kalem oynatmış, irili-ufaklı 76 eser ve 410 makale yazmış olan oldukça üretken bir ilim ve fikir adamıdır. Onun çalışmalarında, dini, kültürü ve medeniyeti unutturulan bir millete, ne yapıp yapıp öz miraslarını, dinlerini ve medeniyetlerini tanıtma ve öğretme çabası görülür.

Hayatı boyunca elde ettiği ilmi müktesebatı ve zengin kaynaklarının yanısıra, sahip olduğu sağlam muhakemesi, ona güçlü bir yorumculuk ve tenkidçilik kabiliyeti kazandırmıştır. Onu, emsallerinden ayıran bu özellik, hemen her eserinde görülmektedir.

Rızaeddin b. Fahreddin'in çalışmalarından, onun Mısır başta olmak üzere Arap alemindeki hem yeni eserlerden, hem de Selefi yaklaşımdan kısmen etkilenmiş olduğu anlaşılmaktadır. Eserlerinde daima hadis, sünnet ve hadis kaynaklarının öncelenmesi üzerinde durmuştur. Ancak o, ne mezhepleri ve mezhep imamlarını, ne de geleneği göz ardı etmiştir.

Onun çalışmalarında dikkatimizi çeken bir başka husus da, onun ameli sünnete yaptığı vurgudur. Sahabeden itibaren yaşanarak tevarüs edilen sünnet ya da tatbikat ona göre rivayet edilegelen hadislerden daha fazla belirleyicidir.

Rızaeddin b. Fahreddin'in en önemli yanı ise, onun eleştirel bir bakış açısına sahip olmasının yanında, araştıran, soruşturan, sorgulayan bir anlayışı hayatı boyunca sürdürmüş olması ve bunu bütün açıklığıyla da eserleri- 
ne yansıtabilmesidir. Taklidden ve taassuptan uzak, doğruyu, hakikatı arayan örnek bir ilim adamı profili çizmektedir. Bu çok yönlü okuma, her mezhebe, her alime açık olma, farklı ilim dallarıyla ilgilenme, kendisine her türlü bilgi ve hikmetten yararlanma gibi geniş bir perspektif kazandırmıştır. İste bütün bunlar da onu akranlarından ayrıcalıklı kılmıştır.

Hayatı ve eserleri hakkında birçok çalışmalara konu olan Rızaeddin Fahreddin'in, şimdiye kadar ihmal edilen hadisçiliğini ele aldığımız bu makale, yukarıdan beri söylenenlerin âdeta bir ispatı niteliğindedir. Hadis tarihi, Hadis imamları ve Hadis kaynaklarıla ilgili tespit ve değerlendirmeleri, genel olarak Hadis ve Sünnet'e bakışı ve yaklaşımı, bilhassa yaklaşık bir asır öncesinden yapmış olduğu orijinal ve tutarlı yorumları, onun başarılı bir hadisçi olduğunu göstermeye yeterlidir.

Bir makalenin sınırları çerçevesinde ele aldığımız Rızaeddin Fahreddin'in hadisçiliği ile şerhçiliği, aslında iki ayrı yüksek lisans tezi olarak çalışılmalıdır. Müstakil olarak yapılacak bu tür çalışmalarla onun hadisçiliği ve değerlendirmeleri daha detaylı bir şekilde ortaya konulacaktır.

Ayrıca onun halen el yazması olarak çeşitli kütüphanelerde ilgi bekleyen kıymetli eserlerinin bir an evvel neşredilmesi gereklidir. Aynı şekilde geçen asırda basılmış olan değerli çalışmaları ofset olarak da olsa yeniden basılarak okuyucularıyla buluşmalıdır. Bilindiği gibi Rızaeddin b. Fahreddin'in bütün eserleri kadim Tatarcayla kaleme alınmıştır. Aradan geçen bir asırlık zaman diliminden sonra günümüz Tatarları kendi harflerini de, kadim Tararcayı da unutmuşlardır. Dolayısıyla kadim Tatarcayla yazılmış olan bazı eserlerin, özellikle Tataristan'daki öğrencilerin istifadesine sunulması bakımından günümüz Tatarcasına, Kril harflerine dönüştürerek hatta Rusça'ya çevirilerek neşredilmesi gerekmektedir. 